BNWL-1012

UC-40

$2-$

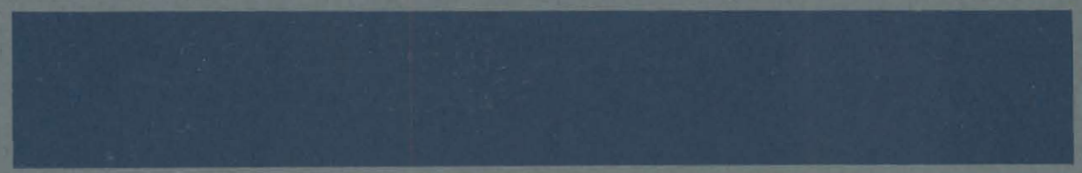

ULTRASONIC VELOCITIES

AND

CRITICAL-ANGLE-METHOD CHANGES

IN IRRADIATED 304 STAINLESS STEEL

MARCH 1969

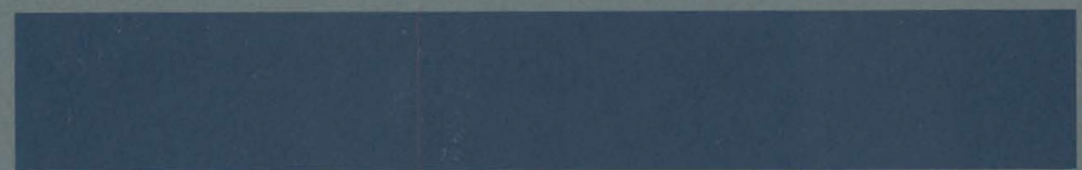

AEC RESEARCH \&

DEVELOPMENT REPORT

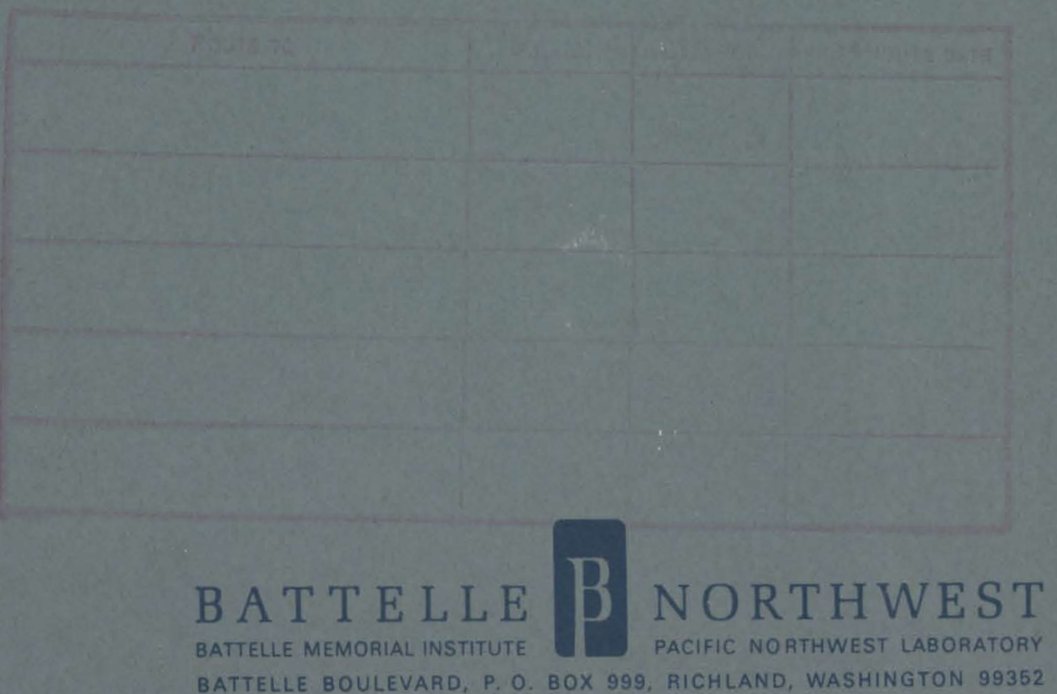




\section{LEGAL NOTICE}

This report was prepared as an account of Government sponsored work. Neither the United States, nor the Commission, nor any person acting on behalf of the Commission:

A. Makes any warranty or representation, expressed or implied, with respect to the accuracy, completeness, or usefulness of the information contained in this report, or that the use of any information, apparatus, method, or process disclosed in this report may not infringe privately owned rights; or

B. Assumes any liabilities with respect to the use of, or for damages resulting from the use of any information, apparatus, method, or process disclosed in this report.

As used in the above, "person acting on behalf of the Commission" includes any employee or contractor of the Commission, or employee of such contractor, to the extent that such employee or contractor of the Commission, or employee of such contractor prepares, disseminates, or provides access to, any information pursuant to his employment or contract with the Commission, or his employment with such contractor.

\section{PACIFIC NORTHWEST LABORATORY \\ RICHLAND, WASHINGTON \\ operated by}

BATTELLE MEMORIAL INSTITUTE

for the

UNITED STATES ATOMIC ENERGY COMMISSION UNDER CONTRACT AT(45-1)-1830 


\title{
ULTRASONIC VELOCITIES AND CRITICAL-ANGLE-METHOD \\ CHANGES IN IRRADIATED 304 STAINLESS STEEL
}

\author{
By \\ D. 0 . Hunter \\ Methods Development Section \\ Nondestructive Testing Department \\ Systems \& Electronics Division
}

March 1969

FIRST UNRESTACTED

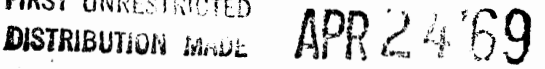

\author{
BATTELLE MEMORIAL INSTITUTE \\ PACIFIC NORTHWEST LABORATORY \\ RICHLAND, WASHINGTON \\ 99352
}

Printed in the United States of America Available from

Clearinghouse for Federal Scientific and Technical Information National Bureau of Standards, U. S. Department of Commerce Springfield, Virginia 22151

Price: Printed Copy $\$ 3.00$; Microfiche $\$ 0.65$ 


\title{
ULTRASONIC VELOCITIES AND CRITICAL-ANGLE-METHOD CHANGES IN IRRADIATED 304 STAINLESS STEEL
}

\author{
$\underline{\text { ABSTRACT }}$ \\ Ultrasonic critical-angle-method amplitude changes and ultrasonic \\ shear and longitudinal velocities changes are measured on reactor \\ irradiated AISI 304 stainless steel. \\ For specimens irradiated at temperatures between $140{ }^{\circ} \mathrm{F}$ and \\ $350^{\circ} \mathrm{F}$, shear velocity decreased from about $0.1 \%$ at $1.5 \times 10^{18} \mathrm{nvt}$ \\ $>1 \mathrm{MeV}$ to about $1.25 \%$ at $1 \times 10^{20} \mathrm{nvt}>1 \mathrm{MeV}$; longitudinal velocity \\ decreased from about $0.1 \%$ to $0.5 \%$ for the same neutron fluences. \\ Measurements of velocities changes for specimens irradiated at \\ temperatures between $610^{\circ} \mathrm{F}$ and $680^{\circ} \mathrm{F}$ were inconclusive due to the \\ small changes. There were indications, however, that high temperature \\ irradiated specimens had experienced increased velocities before \\ decreasing velocities trends were established. \\ The trends of critical-angle-method amplitude changes, as \\ functions of irradiation parameters, are generally comparable to \\ the trends of velocities changes. \\ Apparent changes in elastic constants are calculated by using \\ measured changes in density and in shear and longitudinal velocities. \\ Measurement methods and apparatus are described.
}


TABLE OF CONTENTS

LIST OF FIGURES

LIST OF TABLES .

INTRODUCTION

SUMIMARY

CONCLUSIONS

EXPERIMENTAL PROCEDURE

Specimens Preparation and Irradiation

Measurement Methods

Changes in Shear Velocity, $\Delta \mathrm{V}_{\mathrm{S}} / \mathrm{V}_{\mathrm{S}}$

Changes in Longitudinal Velocity, $\Delta V_{L} / V_{L}$

Changes in Critical-Angle-Method

Signal Amplitude, $\triangle A_{C A}$

Mechanical Apparatus RESULTS

Changes in Shear Velocity

Changes in Longitudinal Velocity

Changes in Elastic Properties.

Changes in Critical-Angle-Method Signal Amplitude

Scatter and Error. DISCUSSION

General

Effects of Irradiation Temperature

Effects of Variation in Neutrons Energy Spectrum

Causes of Changes in Velocities

Relationship of Changes in Ultrasonic Velocities

to Change in Ductility.

Suggested Applications.

ACKNOWLEDGEMENTS

REFERENCES

DISTRIBUTION 


\section{LIST OF FIGURES}

1 The Effect of Test Temperature on the Ductility of Irradiated AISI 304 Stainless Steel in the Annealed Condition

2304 Test Specimens' Positions in Donor Plate

3 Test Specimens in Various Stages of Encapsulation

4 Test Specimens Being Encapsulated With Wire Spacers

5 Typical Capsules Used for ETR Reactor Ambient Temperature Positions' Irradiations

6 Typical Quadrant Capsules Assemblies Used for ETR Reactor G7-High-Temperature-Loop Irradiations in Irradiated Steel

10 Critical-Angle Method for Measuring Ultrasonic Properties Changes in Irradiated Steel

11 Hot-Cell Specimen Handling Area Seen Through Hot-Cell Window

12 Gatling-Gun Specimens-Storage-Cask 19

13 Change in Ultrasonic Shear Velocity in Irradiated 304

14 Change in Ultrasonic Longitudinal Velocity in Irradiated 304

15 Distribution of Change-in-Longitudinal-Velocity

Measurements for Twenty-Two EBR-II Irradiated

304 Miniature Tensile-Creep Specimens

16 Change in Ultrasonic Critical-Angle-Method

Signal Amplitude for Irradiated 304

17 Effects of Neutron Irradiation on Ultrasonic

Shear Velocity and on Room Temperature

Ductility for Annealed 304 Steel 


\section{LIST OF TABLES}

I Neutron Irradiation Data on Test Specimens

II Indicated and Calculated Irradiation Temperature Data on Test Specimens

III Change in Shear Velocity For Irradiated 304

IV Change in Longitudinal Velocity For Irradiated 304

V Swelling and Change in Density, Irradiated 304

VI Elastic Properties for Unirradiated 304 Steel, and Apparent Changes in Elastic Properties for Two Irradiated 304 Steel Specimens

VII Change in Critical Angle Signal Amplitude in Irradiated 304

VIII Changes in Shear Velocity, Longitudinal Velocity, and Critical Angle Signal Amplitude for 304 Control Specimens 


\title{
ULTRASONIC VELOCITIES AND CRITICAL-ANGLE-METHOD \\ CHANGES IN IRRADIATED 304 STAINLESS STEEL
}

\author{
D. 0 . Hunter
}

\section{INTRODUCTION}

Austenitic stainless steels have been shown to suffer loss of ductility when irradiated. $(1,2)$ Decrease in ductility is particularly severe, due to the combined effects of irradiation and temperature, at elevated temperatures although the greatest change between the irradiated and unirradiated conditions occurs at lower test temperatures, as shown in Figure 1. Degraded ductility in reactor structural steels may impose costly operational limitations and, if undetected, could lead to even more costly mechanical failures. A nondestructive method for measuring the irradiation effects leading to decreases in ductility would help alleviate the problems brought on by an unknown decrease in ductility。

This report includes results and a description of methods used to make ultrasonic measurements in neutron irradiated 304 stainless steel. Changes in shear and longitudinal velocities and critical-anglemethod signal amplitude are determined as a function of neutron fluence $>1 \mathrm{MeV}$, with irradiation temperature as a parameter.

\section{SUMMARY}

Measurements of changes in ultrasonic shear velocity. longitudinal velocity, and critical-angle-method signal amplitude were made on 

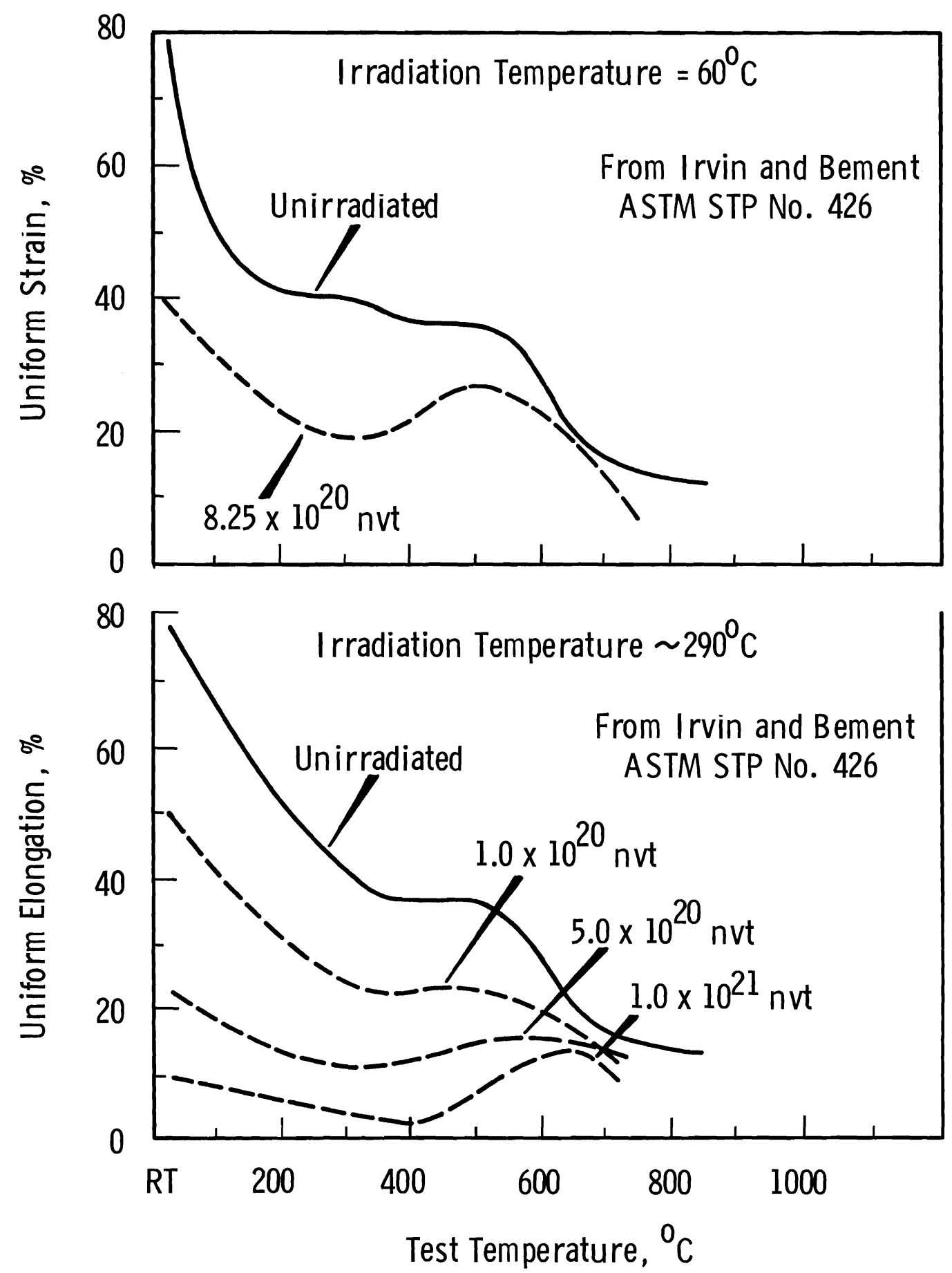

FIGURE 1

The Effect of Test Temperature on the Ductility of Irradiated AISI 304 Stainless Steel in the Annealed Condition 
irradiated 304 steel. For specimens irradiated at temperatures between $140^{\circ} \mathrm{F}$ and $350^{\circ} \mathrm{F}$ :

shear velocity decreased as a function of neutron fluence

$>1 \mathrm{MeV} ; \Delta \mathrm{V}_{\mathrm{S}} / \mathrm{V}_{\mathrm{S}}$ varied from about $-0.15 \%$ at $1.5 \times 10^{18} \mathrm{nvt}$ to about $-1.25 \%$ at $1.0 \times 10^{20}$ nvt;

- longitudinal velocity decreased as a function of neutron fluence $>1 \mathrm{MeV} ; \Delta \mathrm{V}_{\mathrm{L}} / \mathrm{V}_{\mathrm{L}}$ varied from about $-0.12 \%$ at $1.5 \mathrm{x}$ $10^{18}$ nvt to about $-0.51 \%$ at $1.0 \times 10^{20} \mathrm{nvt}$;

- critical-angle-method signal amplitude changed approximately in proportion to the velocity changes.

Decreases in velocities and density suggest decreases in shear, bulk, and Young's elastic moduli, and an increase in Poisson's ratio.

For specimens irradiated at temperatures between $610^{\circ} \mathrm{F}$ and $680^{\circ} \mathrm{F}$, ultrasonic changes were too small to be conclusive. Velocity measurements indicated decreasing trends but with possible net increases at the lower neutron fluences.

\section{CONCLUSIONS}

The ultrasonic methods described herein are capable of detecting a type of irradiation damage which remains relatively stable at irradiation temperatures less than about $350{ }^{\circ}$. Other forms of irradiation damage still stable at irradiation temperatures between $610^{\circ} \mathrm{F}$ and $680^{\circ} \mathrm{F}$ are not easily detected. Greater sensitivity to high temperature irradiation damage would result if reference measurements taken prior to irradiation were available during 
post-irradiation measurements.

Besides applications related to measuring radiation damage to structural components or surveillance specimens, ultrasonic methods appear to be useful in the laboratory for studies pertaining to temperature related irradiation damage and damage recovery.

\section{EXPERIMENTAL PROCEDURE}

The irradiations and measurements to be described herein were conducted concurrently with irradiations and measurements on A302-B and $A 542-B$ low alloy steels. A detailed report pertaining to $A 302-B$ and $A 542-B$ steels has been separately issued. (3)

\section{Specimens Preparation and Irradiation}

Specimens were machined from donor plate No. B-55697, a $\frac{1}{2}$ in. thick plate included in the stockpile used for the "Irradiation Effects on Reactor Structural Materials Program". Fabrication history, briefly, is as follows:

(1) hot rolled in 17 passes from 6 in. to $\frac{1}{2}$ in. plate at $2250^{\circ} \mathrm{F}$ (start of rolling) to $1700^{\circ} \mathrm{F}$ (end of rolling);

(2) heated one hour at $2000^{\circ} \mathrm{F}$, then water quenched;

(3) pickled, then abrasive cut to size.

Specimens were machined from the donor plate as shown in Figure 2. Before machining, the plate section was solution annealed at $1950{ }^{\circ} \mathrm{F}$ for one hour, in vacuum, and furnace cooled. After machining to the finished specimen, all specimens except one unirradiated control specimen were stress-relieved, $650^{\circ} \mathrm{F}$ for 


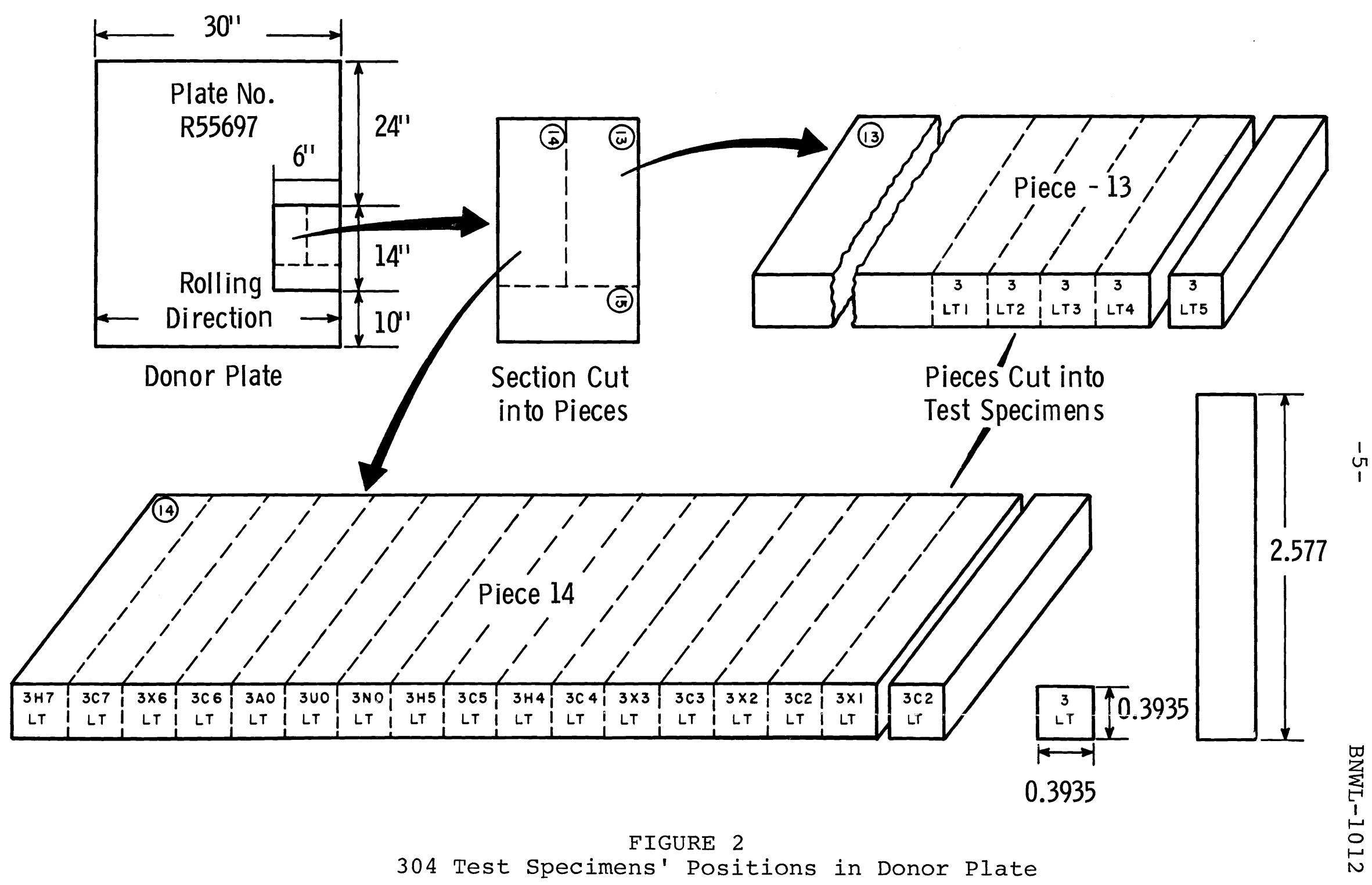


20 hours with furnace cooling. Typical Rockwell A hardness measurements following stress relieving were $R_{A}=44$ to 46 。

Finished specimens were encapsulated in 304 SS capsules as shown in Figure 3. A helium gap was used to enable control of specimen temperature by slowing transfer of gamma heat. In some specimen capsules, spacer wires were used, as shown in Figure 4, to assure uniform gap spacing. The individual encapsulated specimens were mounted in irradiation-capsules, as shown in Figures 5 and 6, for reactor irradiation.

Prior to finish machining, all specimens were identified with nomenclature as shown in Figure 2 and explained as follows:

(1) The first character on the first line, a number, identifies material; "3" designates 304 steel ("1" designates A302-B, and "2" designates A542-B);

(2) the second character on the first line, a letter, identifies irradiation temperature; "C" designates cold or $140^{\circ} \mathrm{F}$ to $350^{\circ} \mathrm{F}$; "H" designates hot or $610^{\circ} \mathrm{F}$ to $680^{\circ} \mathrm{F}$; all other letters pertain to unirradiated control specimens;

(3) the third character on the first line, a number, identifies sequential position with respect to irradiation dosage; i.e., "1" received the least exposure and "7" received the most exposure;

(4) the first character on the second line, a letter, designates the predominant rolling direction associated with the specimens' 


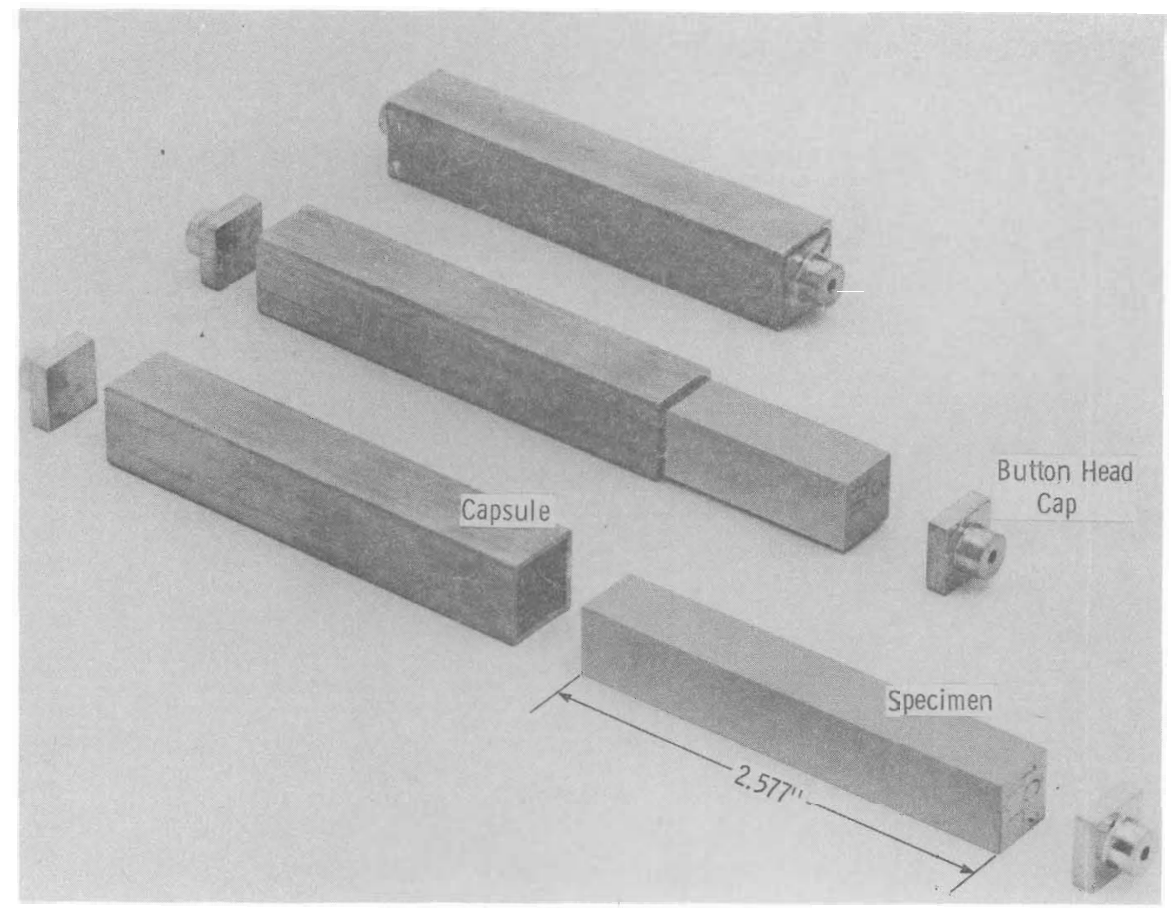

FIGURE 3

Test Specimens in Various Stages of Encapsulation

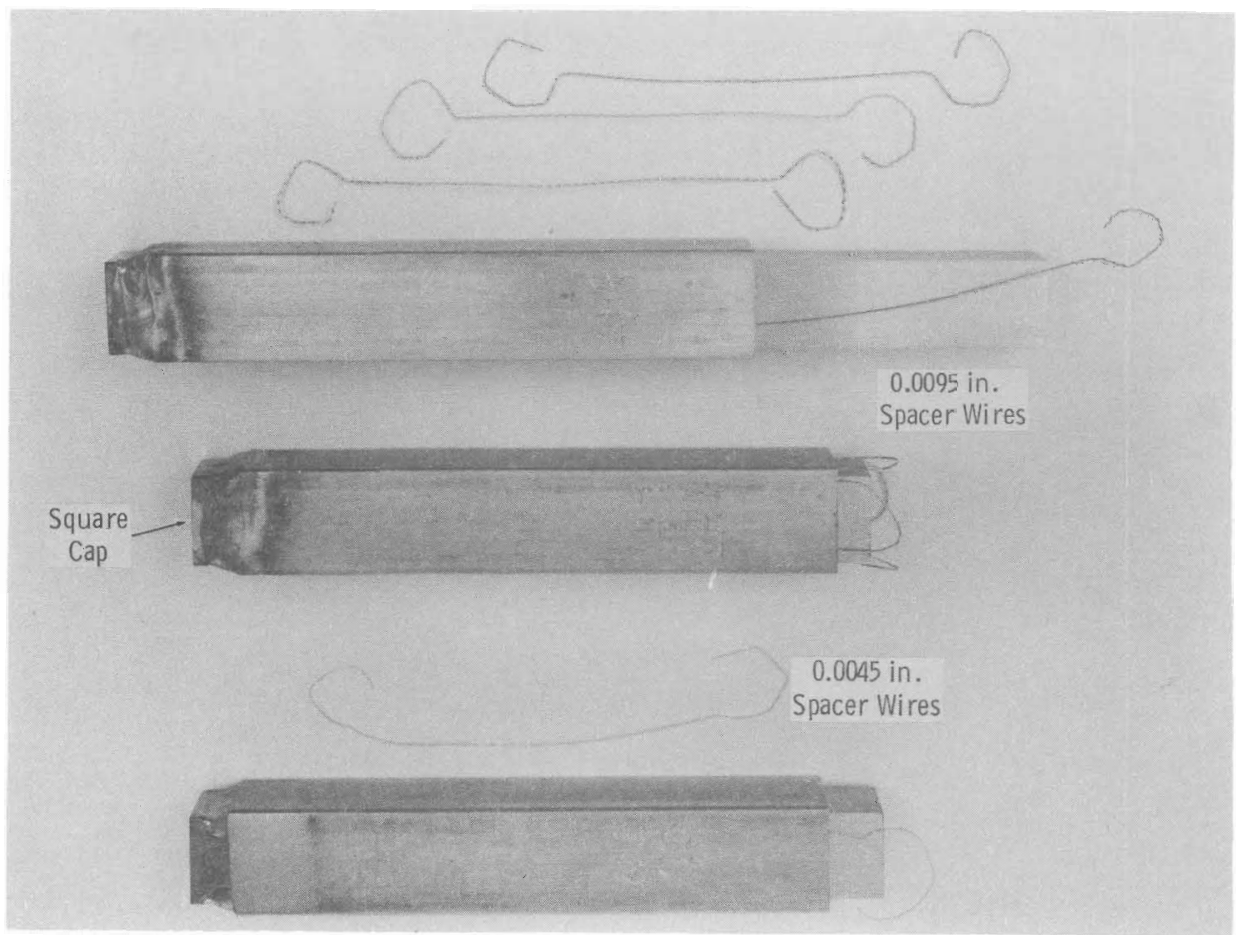

FIGURE 4

Test Specimens Being Encapsulated with Wire Spacers 


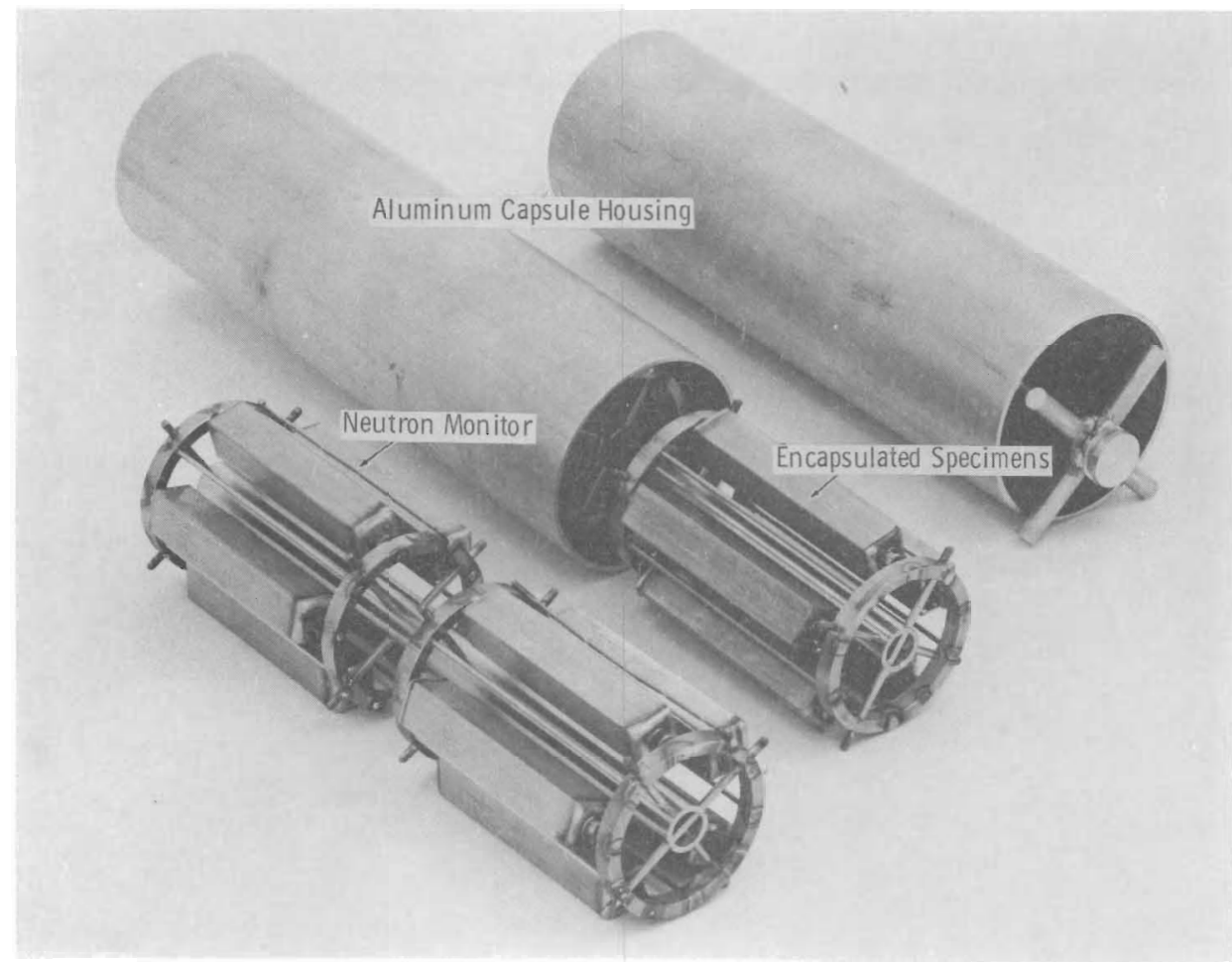

FIGURE 5
Typical Capsules used for ETR Reactor Ambient Temperature Positions' Irradiations

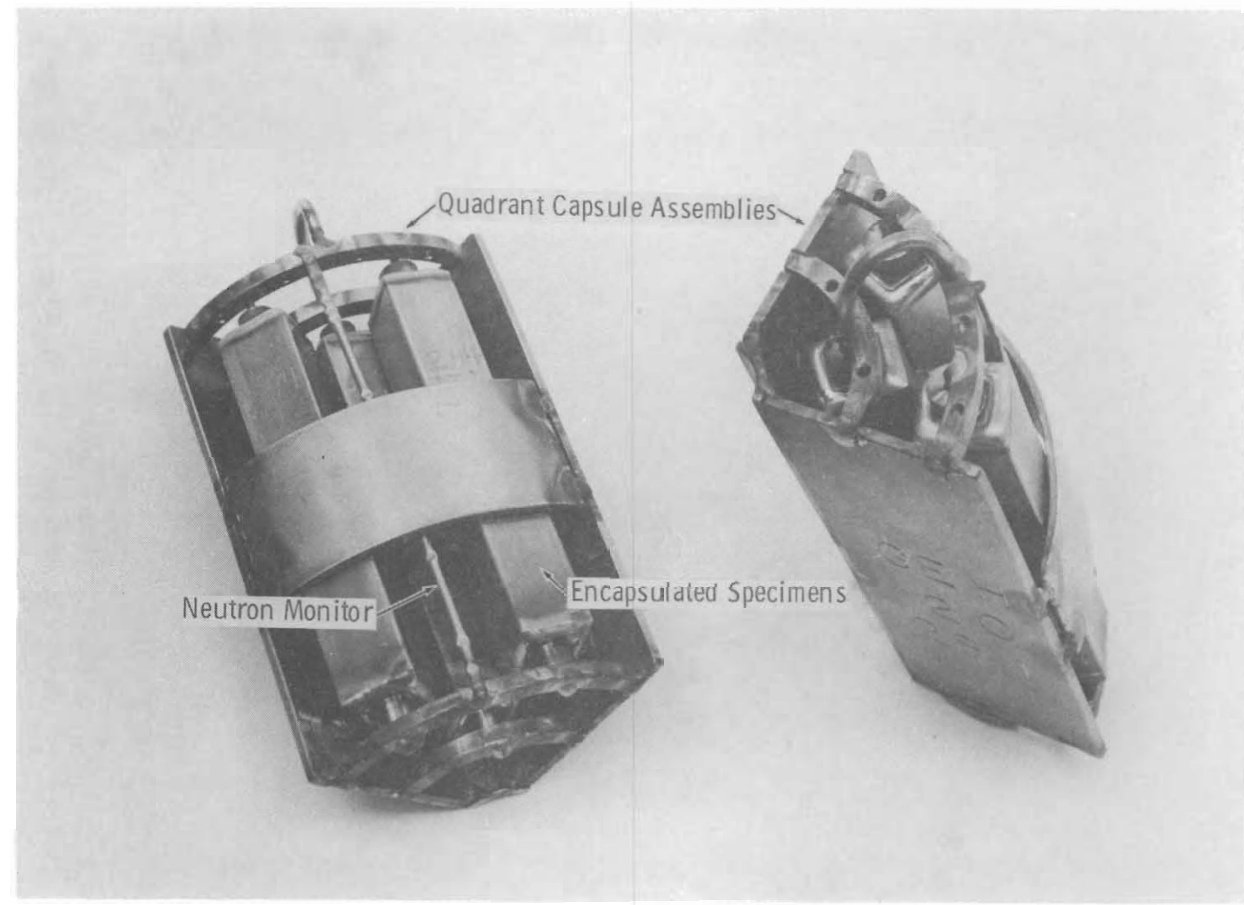

FIGURE 6

Typical Quadrant Capsules Assemblies used for ETR Reactor G7-High-Temperature-Loop Irradiations 
long dimension (2.577 in.); "L" designates longitudinal rolling direction; transverse machined specimens ("T") were not irradiated;

(5) the second character on the second line, a letter, pertains to surface position in donor plate and may be ignored for 304 since a specimen's cross-section dimension is about the same as donor plate thickness;

(6) the third character on the second line, a number, pertains to control specimens identification (see Table VIII). Positions of ultrasonic measurements on a test specimen are identified by referring to Figure 7. Specimens' sides and positions are noted in tables of data to follow and may be identified by referring to Figure 7.

Irradiation was done at the Experimental Test Reactor (ETR), National Reactor Test Station (NRTS), Idaho。 Irradiation data is shown in Table I which includes data on low alloy steels as well. Deencapsulation and other post-irradiation handling was done at Pacific Northwest Laboratory (PNL). Determination of neutron exposure at each capsule reactor position was done by activation analysis of neutron monitors attached to each capsule.

Irradiation experiments were designed in such a manner that specimens were irradiated in one of two different temperature ranges: $140^{\circ} \mathrm{F}$ to $350^{\circ} \mathrm{F}$ and $610^{\circ} \mathrm{F}$ to $680^{\circ} \mathrm{F}$. Temperature monitors were included in a dummy specimen in each capsule assembly so that 

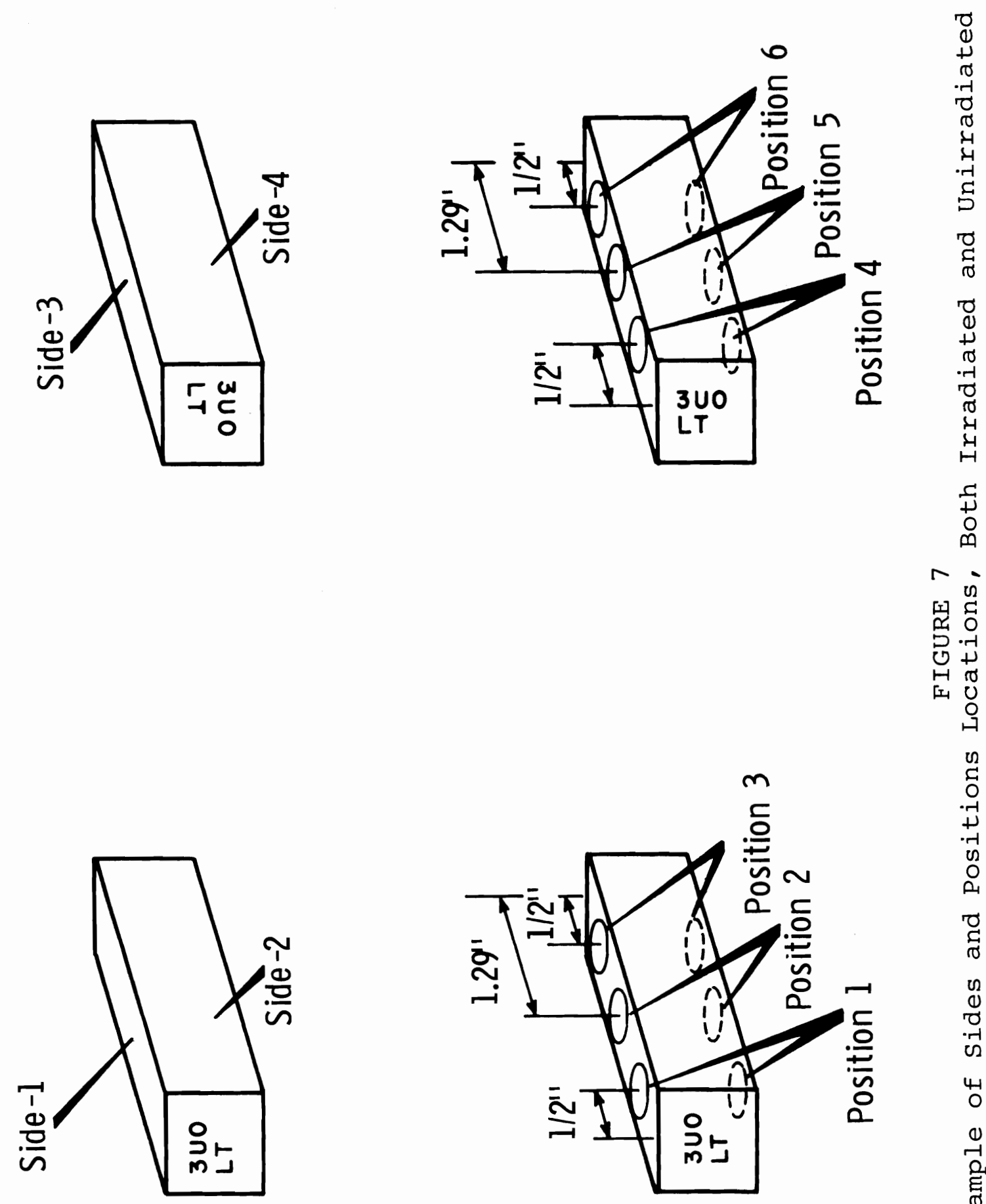
N 2
प딜
D.
$0+4$
H 100
II U م
吕

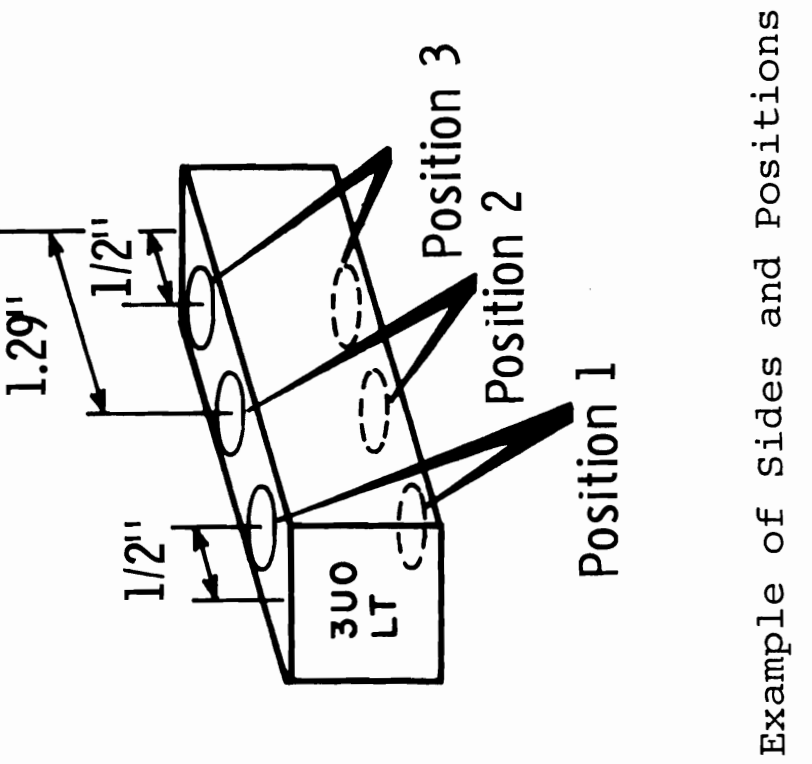


TABIE I

NEUTRON IRRADIATION DATA ON TEST SPECIMENS

\begin{tabular}{|c|c|c|c|c|c|c|c|c|c|c|}
\hline $\begin{array}{l}\text { Test } \\
\text { Speci- } \\
\text { mens } \\
\text { Series }\end{array}$ & $\begin{array}{c}\text { Indic- } \\
\text { ated } \\
\text { Fast } \\
\text { Flux } \\
\text { Fe Wire, } \\
\text { nv } 14 \\
\times 10^{14} \\
\end{array}$ & $\begin{array}{c}\text { Indic- } \\
\text { a.ted } \\
\text { Fast } \\
\text { Flux } \\
\text { Ni Wire, } \\
\text { nv } 14 \\
\times 10^{14} \\
\end{array}$ & $\begin{array}{l}\text { Ave. of } \\
\text { cor- } \\
\text { rected } \\
\text { Fast } \\
\text { Flux, } \\
\text { nv } 14 \\
\times 10^{14}\end{array}$ & $\begin{array}{l}\text { Indic- } \\
\text { ated } \\
\text { Thermal } \\
\text { Flux } \\
\text { Al-Co } \\
\text { Wire, } \\
\text { nv } \\
\times 10^{14} \\
\end{array}$ & $\begin{array}{l}\text { Cor- } \\
\text { rected } \\
\text { Thermal } \\
\text { Flux, } \\
\text { nv } \\
\times 10^{14}\end{array}$ & $\begin{array}{r}\text { Eff. } \\
\text { Irrad. } \\
\text { Time, } \\
\text { Sec, } \\
\times \quad 10 \\
\end{array}$ & $\begin{array}{c}\text { Fast } \\
\text { Fluence } \\
>1 \mathrm{MeV}, \\
\text { nvt } \\
\times 10^{18} \\
\end{array}$ & $\begin{array}{c}\text { Thermal } \\
\text { Fluence } \\
2200 \\
\mathrm{~m} / \mathrm{sec} ., \\
\text { nvt } 18 \\
\times \quad 10 \\
\end{array}$ & $\begin{array}{l}\text { Thermal } \\
\text { to Fast } \\
\text { Flux } \\
\text { Ratio }\end{array}$ & \\
\hline AlI C1 & 0.0070 & 0.0080 & 0.0081 & 0.102 & 0.098 & 1.82 & 1.47 & 17.8 & $12.1: 1$ & \\
\hline $\mathrm{All} \mathrm{C} 2$ & 0.0137 & 0.0148 & 0.0153 & 0.153 & 0.145 & 1.82 & 2.78 & 26.4 & $9 \cdot 5: 1$ & \\
\hline A11 C3 & 0.0361 & 0.0378 & 0.0373 & 0.633 & 0.645 & 1.82 & 6.79 & 117.3 & $17 \cdot 3: 1$ & \\
\hline$\Lambda \perp 1 \mathrm{C}_{4}^{*}$ & 0.0345 & 0.0362 & 0.0354 & 0.569 & 0.580 & 5.35 & 18.9 & 310.0 & $16.4: 1$ & \\
\hline AlI C5 & 0.2220 & 0.2490 & 0.2850 & 0.934 & 0.882 & 1.79 & 51.0 & 158.0 & $3.1: 1$ & \\
\hline A11 C6 & 0.5280 & 0.5200 & 0.5700 & 1.68 & 1.62 & 1.79 & 102.0 & 290.0 & $2.8: 1$ & $\stackrel{1}{-}$ \\
\hline $\begin{array}{l}\text { 1 LT, } 1 \mathrm{LN} \\
\mathrm{C} 7 \& \mathrm{H} 7\end{array}$ & 1.080 & 0.9790 & 1.049 & 2.81 & 2.82 & 1.79 & 188.0 & 505.0 & $2.7: 1$ & $\vec{\imath}$ \\
\hline $\begin{array}{l}\text { 2LT, 3LT } \\
\mathrm{C} 6 \& \mathrm{H} 7\end{array}$ & 1.060 & 0.9500 & 0.9800 & 3.07 & 3.13 & 1.79 & 175.0 & 560.0 & $3.2: 1$ & \\
\hline $\begin{array}{l}1 \mathrm{LT}, 1 \mathrm{LM} \\
\mathrm{H} 4\end{array}$ & 0.0355 & 0.0411 & 0.0454 & 0.138 & 0.119 & 4.19 & 19.0 & $49 \cdot 9$ & $2.6: 1$ & \\
\hline $\begin{array}{l}2 \mathrm{LT}, 3 \mathrm{LT} \\
\mathrm{H} 4\end{array}$ & 0.0352 & 0.0446 & 0.0472 & 0.139 & 0.120 & 4.19 & 19.8 & 50.3 & $2 \cdot 5: 1$ & \\
\hline $\begin{array}{l}1 \mathrm{LT}, 1 \mathrm{LM} \\
\mathrm{H} 5\end{array}$ & 0.2380 & 0.2890 & 0.3120 & 0.552 & 0.475 & 5.34 & 166.0 & 254.0 & $1.5: 1$ & 㫐 \\
\hline $\begin{array}{l}\text { 2LT, 3LT } \\
\text { H5 }\end{array}$ & 0.1760 & 0.1960 & 0.2210 & 0.490 & 0.421 & $5 \cdot 34$ & 118.0 & 224.0 & $1.9: 1$ & $\begin{array}{l}\overrightarrow{1} \\
\overrightarrow{0}\end{array}$ \\
\hline
\end{tabular}


irradiation temperatures could be approximately determined. A listing of indicated irradiation temperatures from post-irradiation examination of temperature monitors is shown in Table II for low alloy steels as well as 304 steel. Also listed in Table II are calculated irradiation temperatures for both the surface and the interior of each specimen. Measurement Methods

Changes in Shear Velocity, $\Delta \mathrm{V}_{\mathrm{S}} / \mathrm{V}_{\mathrm{S}}$

Changes in shear velocity were measured as shown in Figure 8 。 A pulse incident in water on a specimen's surface at about $19^{\circ}$ is mode converted to a shear wave at $45^{\circ}$. With a square cross-section, the pulse travels about the inside as shown. With each revolution, a portion of the pulse's energy leaves the specimen and travels to a receive crystal thus forming on the oscilloscope a series of pulses which are separated in time from each other by the travel time within the specimen. By referencing to one of these echoes on an unirradiated specimen, such as the fifth echo, a measure of change in shear velocity can be obtained by knowing the time position of the fifth echo on an irradiated specimen. After corrections are made for dimensional differences relative to the reference specimen, $\Delta v_{S}$ can be determined from the change in time position, $\Delta \mathrm{T}_{\mathrm{S}}$.

Measurement frequency was about $3 \mathrm{MHz}$.

Changes in Longitudinal Velocity, $\Delta \mathrm{V}_{\mathrm{L}} / \mathrm{V}_{\mathrm{L}}$

Changes in longitudinal velocity were measured as shown in Figure 9. 


\section{TABLE II}

\section{INDICATED AND CALCULATED IRRADIATION}

\section{TEMPERATURE DATA ON TEST SPECIMENS}

\begin{tabular}{|c|c|c|c|c|c|c|c|}
\hline $\begin{array}{l}\text { Test } \\
\text { Speci- } \\
\text { mens } \\
\text { Series }\end{array}$ & $\begin{array}{l}\text { Width } \\
\text { of } \\
\text { Helium } \\
\text { Gap } \\
\text { in. } \\
\end{array}$ & $\begin{array}{l}\text { Fast } \\
\text { Fiux } \\
\text { nv } 14 \\
\times \quad 10^{14} \\
\end{array}$ & $\begin{array}{c}\text { Estim. } \\
\text { Gamma } \\
\text { Heat } \\
\text { watt/gm. }\end{array}$ & $\begin{array}{c}\text { Coolant } \\
\text { Water } \\
\text { Temp. } \\
\mathrm{O}_{\mathrm{F}} \\
\end{array}$ & $\begin{array}{l}\text { Estim. } \\
\text { Inter. } \\
\text { Temp. } \\
\text { (Calcu- } \\
\text { lated) } \\
\text { O }_{F} \\
\end{array}$ & $\begin{array}{l}\text { Estim. } \\
\text { Surface } \\
\text { Temp. } \\
\text { (Calcu- } \\
\text { lated) } \\
\text { O }_{F} \\
\end{array}$ & $\begin{array}{c}\text { Indicated } \\
\text { Surface } \\
\text { Temp., T, } \\
\text { (Temp. } \\
\text { Monitors) } \\
\text { OF }_{\text {F }} \\
\end{array}$ \\
\hline C & 0.0015 & 0.0081 & 0.116 & 140 & 142 & 141 & $T<312$ \\
\hline $\mathrm{C} 2$ & 0.0015 & 0.0153 & 0.224 & 140 & 144 & 143 & $\mathrm{~T}<312$ \\
\hline C3 & 0.0015 & 0.0373 & 0.535 & 140 & 149 & 145 & $T<312$ \\
\hline $\mathrm{C} 4$ & 0.0025 & 0.0354 & 0.506 & 140 & 150 & 147 & $T<312$ \\
\hline $\mathrm{C} 5$ & 0.0055 & 0.2850 & 4.08 & 140 & 270 & 242 & $\mathrm{~T}<312$ \\
\hline C6 & 0.0015 & 0.5700 & 8.15 & 140 & 277 & 224 & $312<T<349$ \\
\hline $\begin{array}{l}\text { C7, } 1 \mathrm{LT} \\
\& 1 \mathrm{LM}\end{array}$ & 0.0015 & 1.049 & 15.0 & 140 & 392 & 294 & $312<\pi<349$ \\
\hline $\begin{array}{l}\mathrm{C7}, 2 \mathrm{LT} \\
\therefore 3 \mathrm{LT}\end{array}$ & 0.0015 & 0.980 & 14.0 & 140 & 376 & 285 & $312<T<349$ \\
\hline $\begin{array}{l}\mathrm{H} 7, \quad \text { IT } \\
\&: \text { LN }\end{array}$ & 0.0105 & 1.049 & 15.0 & 140 & 837 & 739 & $610<T<680$ \\
\hline $\begin{array}{l}\mathrm{H} 7,2 \mathrm{LT} \\
8 \mathrm{LTT}\end{array}$ & 0.0105 & 0.980 & 14.0 & 140 & 791 & 700 & $610<T<680$ \\
\hline $\begin{array}{l}\text { H4, 1LT } \\
\& \text { ILM }\end{array}$ & 0.0015 & 0.0454 & 0.650 & 550 & 561 & 557 & $610<\mathrm{T}-680$ \\
\hline $\begin{array}{l}\mathrm{H} 4,2 \mathrm{LT} \\
\& 3 \mathrm{LT}\end{array}$ & 0.0015 & 0.0472 & 0.675 & 550 & 561 & 557 & $610<T<680$ \\
\hline $\begin{array}{l}\mathrm{H} 5,1 \mathrm{LT} \\
\& 1 \mathrm{LM}\end{array}$ & 0.0015 & 0.312 & 4.46 & 550 & 625 & 596 & $610<T<680$ \\
\hline $\begin{array}{l}\mathrm{H} 5,2 \mathrm{LT} \\
\& \text { 3LT }\end{array}$ & 0.0015 & 0.221 & 3.16 & 550 & 603 & 582 & $610<T<680$ \\
\hline
\end{tabular}



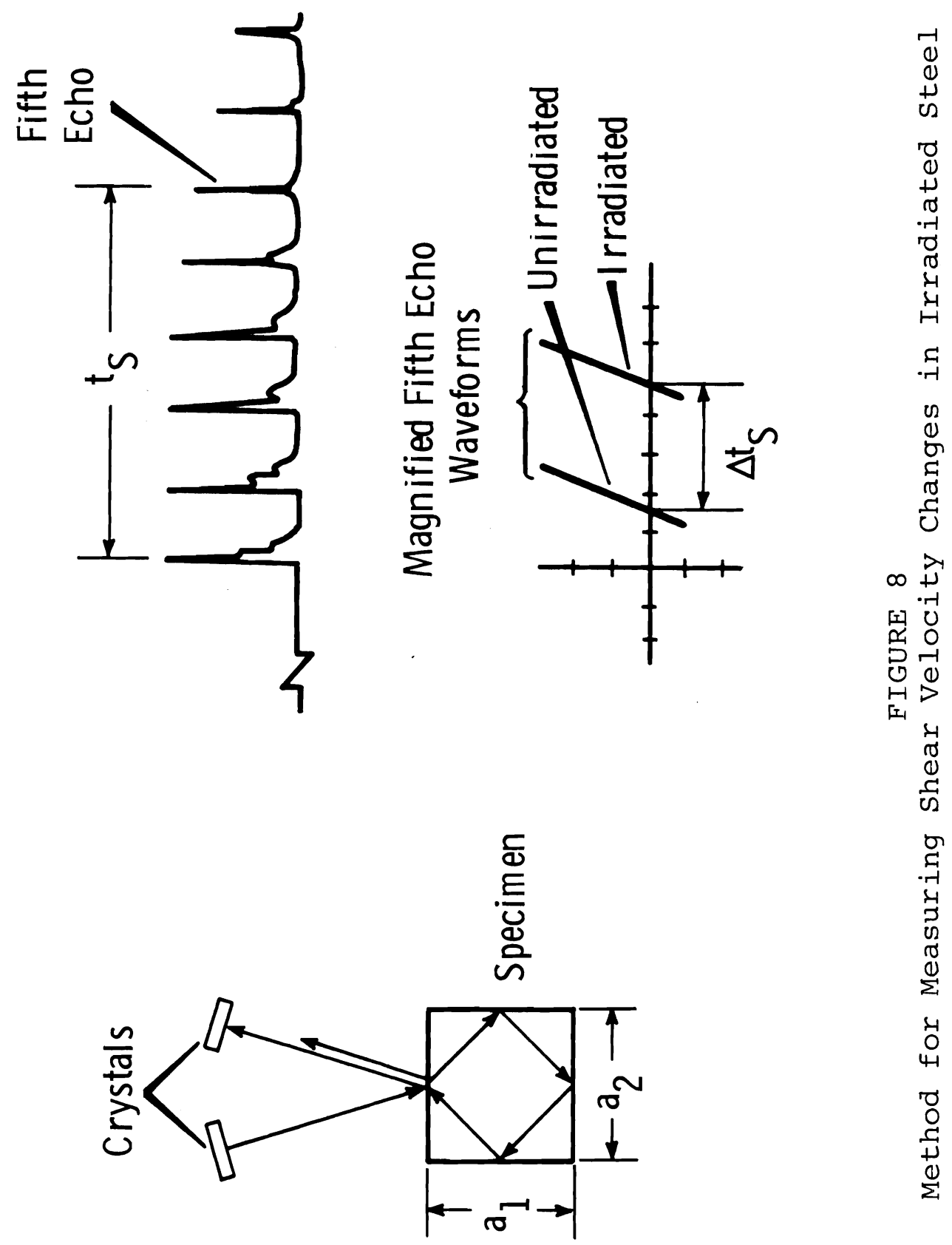

0
0
01
4
0
0
0
0
0
$\Sigma$
4
0
4
0
0
0
01
0
0 

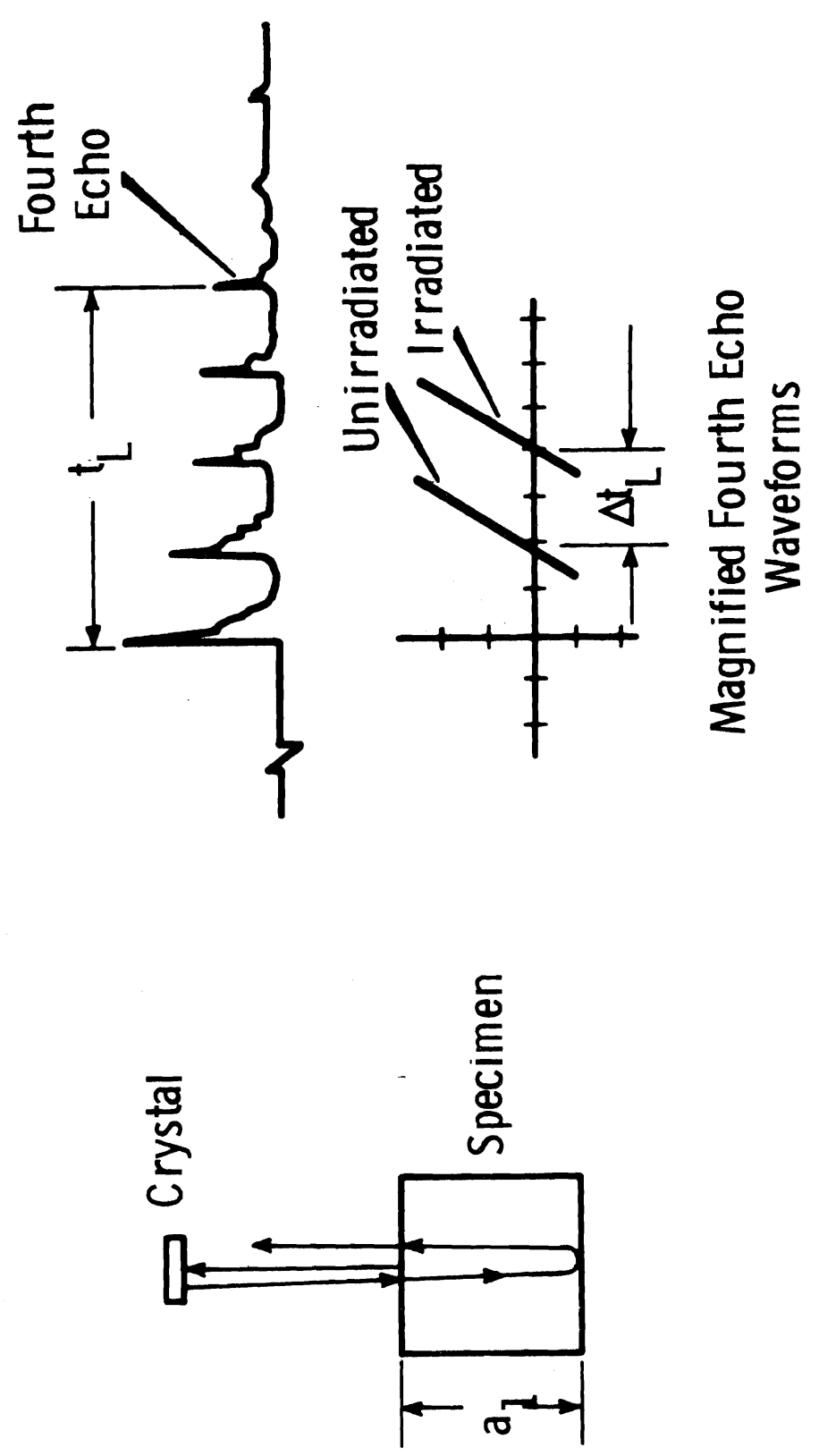
A pulse enters the specimen at normal incidence and reverberates between two opposing faces. Due to the small size of the specimen, interference echoes rapidly build up preventing intellibible interpretation after four or five reverberations. Measurement of $\Delta \mathrm{T}_{\mathrm{L}}$ is made as on the shear velocity method; and $\Delta V_{L}$ is calculated after dimensional corrections are made。

Measurement frequency was about $3 \mathrm{MHz}$ 。

A similar method was used in some measurements on tensile specimens except that change in through-transmission time was measured。

Changes in Critical-Angle-Method Signal Amplitude, $\triangle \mathrm{A}_{\mathrm{CA}}$

Changes in critical-angle-method signal amplitude were measured as shown in Figure 10. A transmit pulse of 20 to 40 oscillations at about $3 \mathrm{MHz}$ is incident in water on the specimen's surface at the critical angle for surface wave generation - about $31^{\circ}$. At this angle, reflections of beam components vary rapidly in phase angle, relative to the incident beam, so that with nominal transmit-beam spread, phase angle changes approaching $360^{\circ}$ become possible. (4) In addition, a narrow portion of the beam is laterally displaced in the direction of propagation. (4) By careful positioning of a receive transducer, it is possible to obtain almost complete cancellation of received beam components, in the central region of the pulse, due to the large changes in phase angle. (5) Since the critical angle for surface waves is dependent upon density and 


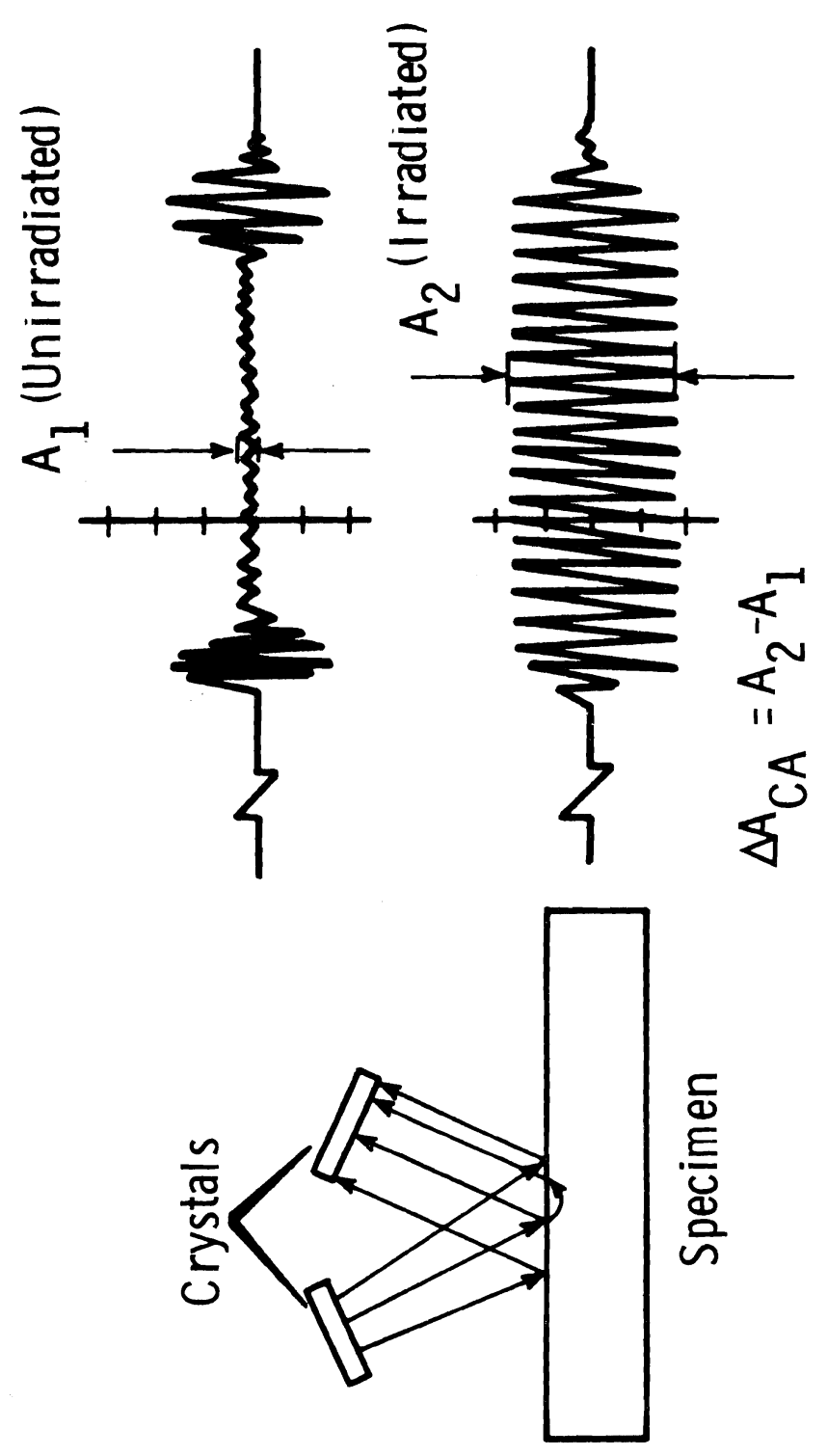


elastic properties of a material, any slight change in these physical properties will cause a redistribution of reflected and re-radiated

energy. (4) The result is that cancellation of received beam components no longer occurs, and a signal appears whose amplitude is related to the changes in elastic properties.

In contrast to the shear and longitudinal velocities changes, which are affected by property changes through most of the specimen's thickness, critical angle changes are caused solely by changes in surface and near-surface properties.

Measurements were taken using two methods:

(1) by measuring RF signal amplitude at a stationary position on the specimen, and

(2) by integrating the $\mathrm{RF}$ signal amplitude over a scanned region of about one inch along the 2.577 in. dimension. Averaging of data from these two methods gave the final data point. More weight was given the integrated scans since error from material scatter would tend to balance-out from results of this method. Mechanical Apparatus

Measurements were made in the 324 Building Shielded Facility at PNL. A view of some of the handling apparatus is seen in Figure 11. Irradiated specimens are remotely removed from storage, ultrasonically cleaned, and loaded in the immersion tank shown at the right. After measurements are completed, specimens are stored in the cask shown in Figure 12. 


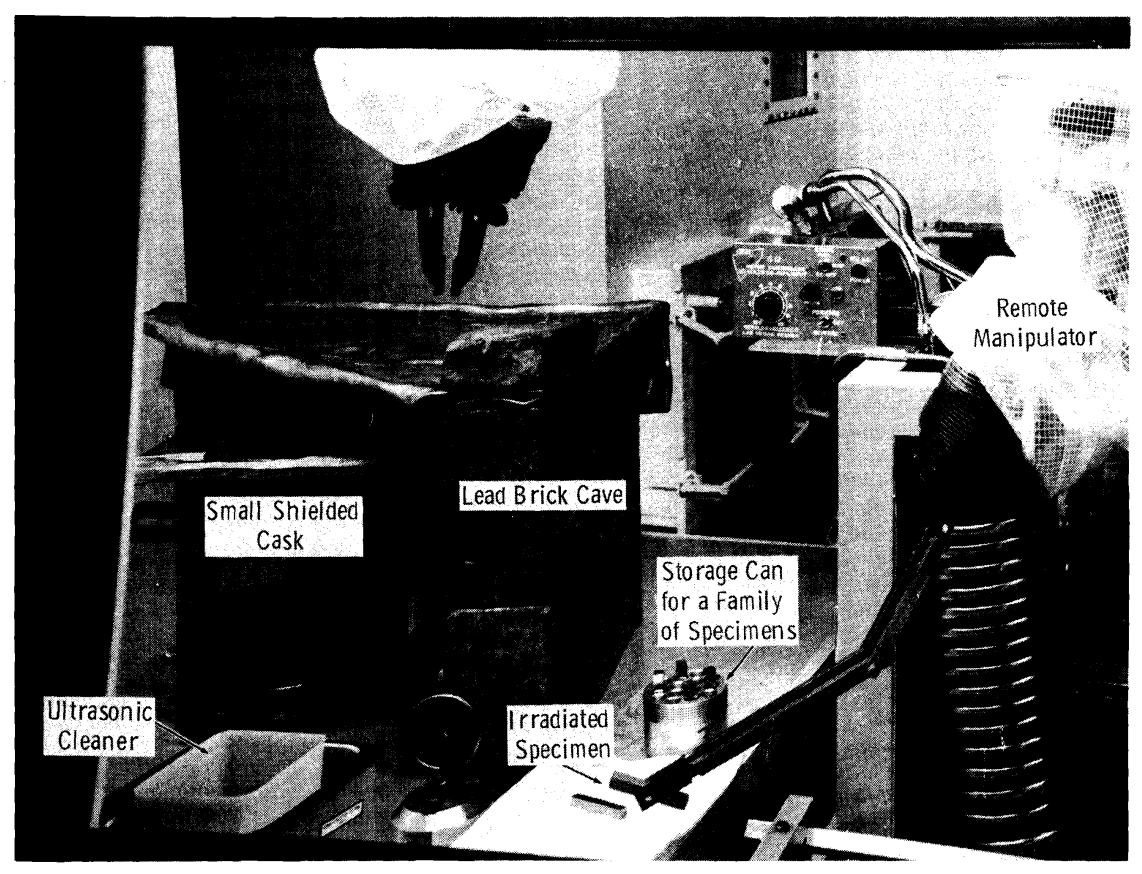

FIGURE 11

Hot-Cell Specimen Handling Area Seen Through Hot-Cell Window

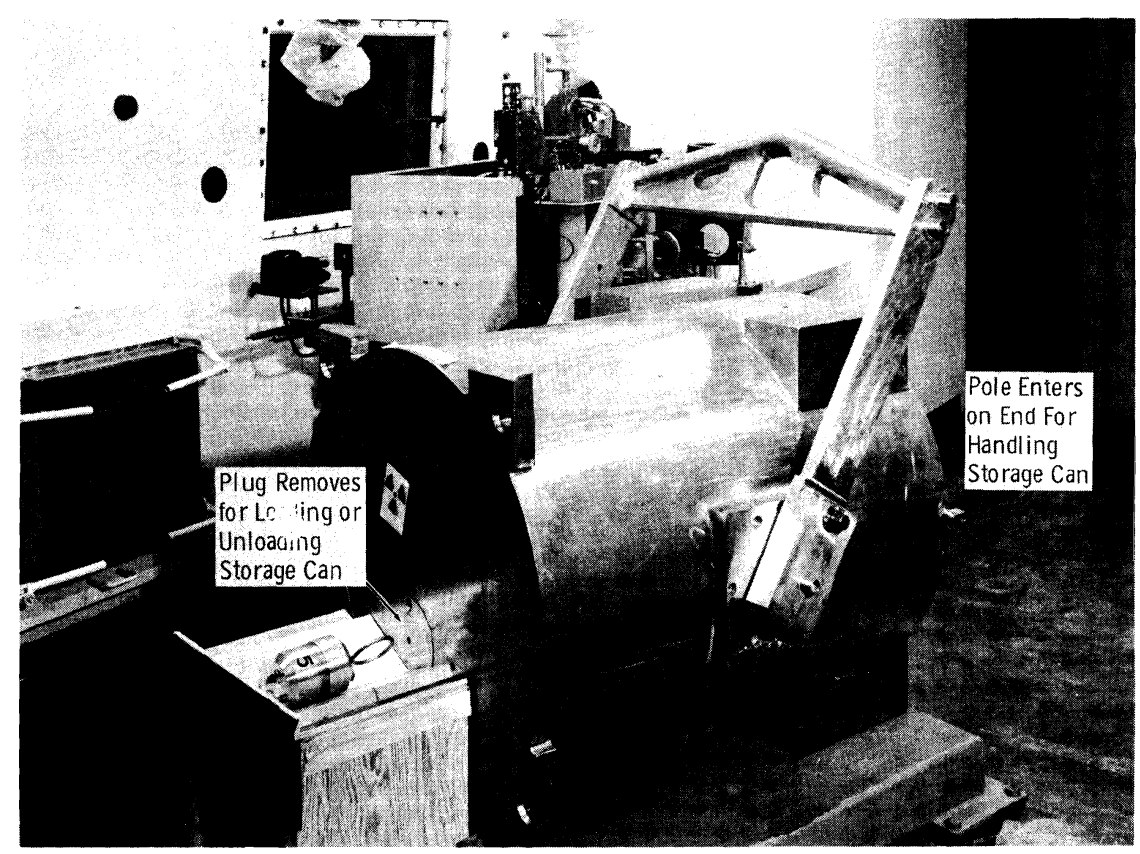

FIGURE 12

Gatling-Gun Specimens-Storage-Cask 


\section{$\underline{\text { RESULTS }}$}

\section{Changes in Shear Velocity}

A tabulation of measurements is shown in Table III. A final data point for a specimen is the scatter corrected average of measurements at three positions (positions 1-4, 2-5, and 3-6) as shown in Figure 7. A description of scatter appears subsequently. Final data points are plotted as curves in Figure 13.

Scatter and error shown in Figures 13, 14, and 16 refer to an estimated possible deviation of irradiated specimen's data points relative to the points plotted in the curves; or it may also show the estimated limits of the zero reference (unirradiated specimen).

From the curves in Figure 13, the following observations are noted:

- Neutron irradiation has caused a decrease in shear velocity in the approximate amount of $0.5 \%$ per decade in the range of $10^{18}$ nvt to $2 \times 10^{20} \mathrm{nvt}(>1 \mathrm{MeV})$ for low temperature reactor irradiations $\left(\mathrm{T} \cong 140^{\circ} \mathrm{F}\right.$ to $\left.350^{\circ} \mathrm{F}\right)$. Ignoring anomalies, the relationship may be expressed as follows:

$$
\Delta V_{S} / V_{S}(\%) \cong-\left(A_{S}+0.5 \log \frac{\phi t}{10^{18}}\right)
$$

$$
\text { where } A_{S} \cong 0.1 \% \text {, and } \phi_{t}=\text { neutron fluence }>1 \mathrm{MeV} \text {. }
$$

- Change in shear velocity appears to be in the decreasing direction for high temperature reactor irradiations $\left(T \cong 610^{\circ} \mathrm{F}\right.$ to $\left.680^{\circ} \mathrm{F}\right)$. The position of the high temperature curve suggests the possibility that $V_{S}$ had increased at lower fluences but 


\section{TABLE III}

CHANGE IN SHEAR VELOCITY FOR IRRADIATED 304

\begin{tabular}{|c|c|c|c|c|c|c|c|}
\hline $\begin{array}{l}\text { Specimen } \\
\text { Identi- } \\
\text { fication }\end{array}$ & $\begin{array}{c}\Delta V_{\mathrm{S}} / \mathrm{V}_{\mathrm{S}} \\
\text { Position } \\
1-4 \\
\%\end{array}$ & $\begin{array}{c}\Delta V_{S} / V_{S} \\
\text { Position } \\
2-5 \\
\% \\
\end{array}$ & $\begin{array}{c}\Delta \mathrm{V}_{\mathrm{S}} / \mathrm{V}_{\mathrm{S}} \\
\text { Position } \\
3-6 \\
\% \\
\end{array}$ & $\begin{array}{c}\Delta \mathrm{V}_{\mathrm{S}} / \mathrm{V}_{\mathrm{S}} \\
\text { Position } \\
1-4 \\
\text { Scatter } \\
\text { Cor- } \\
\text { rected, } \\
\% \\
\end{array}$ & $\begin{array}{c}\Delta \mathrm{V}_{\mathrm{S}} / \mathrm{V}_{\mathrm{S}} \\
\text { Position } \\
2-5 \\
\text { Scatter } \\
\text { Cor- } \\
\text { rected, } \\
\% \\
\end{array}$ & $\begin{array}{c}\triangle \mathrm{V}_{\mathrm{S}} / \mathrm{V}_{\mathrm{S}} \\
\text { Position } \\
3-6 \\
\text { Scatter } \\
\text { Cor- } \\
\text { rected, } \\
\% \\
\end{array}$ & $\begin{array}{c}\text { Average } \\
\triangle V_{S} / V_{S} \\
\text { AlI PoS } \\
\text { itions, } \\
\text { Scatter } \\
\text { Cor- } \\
\text { rected, } \\
\text { of } \\
\end{array}$ \\
\hline $3 \mathrm{C} 1 \mathrm{LT}$ & -0.114 & -0.088 & -0.003 & -0.107 & -0.147 & -0.143 & -0.132 \\
\hline $3 \mathrm{C} 2 \mathrm{LT}$ & -0.161 & -0.183 & -0.130 & -0.193 & -0.245 & -0.241 & -0.226 \\
\hline $3 \mathrm{C} 3 \mathrm{LT}$ & -0.515 & -0.495 & -0.353 & -0.591 & -0.547 & -0.473 & -0.537 \\
\hline $3 \mathrm{C} 4 \mathrm{LT}$ & -0.839 & -0.837 & -0.715 & -0.904 & -0.880 & -0.865 & -0.883 \\
\hline $3 \mathrm{C} 5 \mathrm{LT}$ & -0.986 & -0.979 & -1.040 & -1.019 & -1.022 & -1.221 & -1.087 \\
\hline $3 \mathrm{C} 6 \mathrm{LT}$ & -1.187 & -1.174 & -1.050 & -1.330 & -1.243 & -1.206 & -1.260 \\
\hline 3C7LT & -0.856 & -0.817 & -0.847 & -1.021 & -0.907 & -0.960 & -0.963 \\
\hline 3H4LT & +0.331 & +0.266 & +0.331 & +0.282 & +0.223 & +0.189 & +0.231 \\
\hline 3H5LT & +0.104 & +0.016 & +0.163 & +0.087 & -0.027 & -0.027 & +0.011 \\
\hline $3 \mathrm{H} 7 \mathrm{LT}$ & +0.045 & +0.177 & -0.105 & -0.055 & +0.122 & -0.183 & -0.039 \\
\hline
\end{tabular}




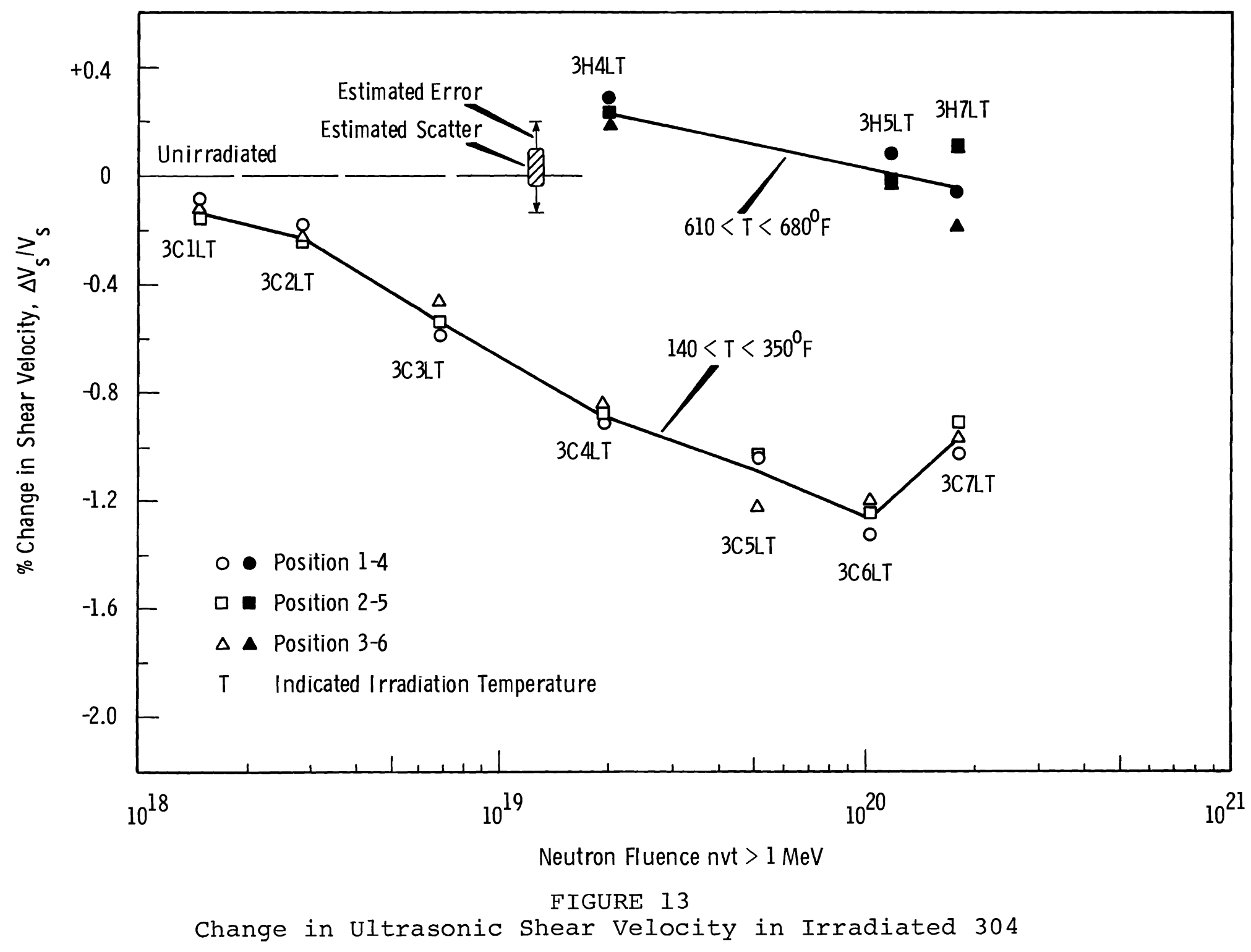


subsequently reversed direction at some fluence still lower than final dosages used in this study. Magnitude of changes are too small to be reliably isolated from possible scatter and error.

- If a sufficient number of measurements can be made so as to reduce scatter error, the radiation damage on low temperature irradiated 304 can be detected at exposures as low as 1 to $2 \mathrm{x}$ $10^{18}$ nvt.

- The low temperature irradiated specimen at $1.75 \times 10^{20}$ nvt has a velocity change much less than would be expected from the curve's trend.

\section{Changes in Longitudinal Velocity}

A tabulation of measurements is shown in Table IV. A final data point for a specimen is the scatter corrected average of measurements at six positions (positions 1 through 6) as shown in Figure 7. Final data points are plotted in Figure 14,

From the curves in Figure 14, the following observations are noted:

- Neutron irradiation has caused a decrease in longitudinal velocity in the approximate amount of $0.22 \%$ per decade in the range of $10^{18}$ nvt to $2 \times 10^{20}$ nvt $(>1 \mathrm{MeV})$ for low temperature reactor irradiations $\left(T \cong 140^{\circ} \mathrm{F}\right.$ to $\left.350^{\circ} \mathrm{F}\right)$. Ignoring anomalies, the relationship may be expressed as follows:

$$
\begin{aligned}
& \Delta v_{I} / v_{L}(\%) \cong-\left(A_{L}+0.22 \log \frac{\phi t}{10^{18}}\right) \\
& \text { where } A_{L} \cong 0.10 \% \text {, and } \phi t=\text { neutron fluence }>1 \mathrm{MeV} \text {. }
\end{aligned}
$$




\section{TABLE-IV}

\section{CHANGE IN IONGITUDINAL VELOCITY}

\section{FOR IRRADIATED 304}

\begin{tabular}{|c|c|c|c|c|c|c|c|}
\hline \multirow{2}{*}{$\begin{array}{l}\text { Specimen } \\
\text { Identi- } \\
\text { fication }\end{array}$} & \multicolumn{6}{|c|}{ Change In Longitudinal Velocity, $\Delta \mathrm{V}_{\mathrm{L}} / \mathrm{v}_{\mathrm{L}}{ }^{*}$} & \multirow{2}{*}{$\begin{array}{l}\text { Average } \\
\Delta V_{I} / V_{I} \\
A I I \text { Pos。 } \\
\text { Scatter } \\
\text { Corrected } \\
-(+0.033), \\
\%\end{array}$} \\
\hline & $\begin{array}{l}\text { Posit- } \\
\text { ion } 1 \text {, } \\
\%\end{array}$ & $\begin{array}{l}\text { Posit- } \\
\text { ion } 2, \\
\%\end{array}$ & $\begin{array}{l}\text { Posit- } \\
\text { ion } 3 \text {, } \\
\%\end{array}$ & $\begin{array}{l}\text { Posit- } \\
\text { ion } 4 \text {, } \\
\%\end{array}$ & $\begin{array}{l}\text { Posit- } \\
\text { ion } 5 . \\
\%\end{array}$ & $\begin{array}{l}\text { Posit- } \\
\text { ion } 6 \text {, } \\
\%\end{array}$ & \\
\hline $3 \mathrm{C} 1 \mathrm{LT}$ & -0.113 & -0.047 & -0.036 & -0.123 & -0.076 & -0.121 & -0.119 \\
\hline $3 \mathrm{C} 2 \mathrm{LT}$ & -0.206 & -0.047 & -0.127 & -0.158 & -0.148 & -0.121 & -0.168 \\
\hline $3 \mathrm{C} 3 \mathrm{LT}$ & -0.286 & -0.253 & -0.166 & -0.300 & -0.287 & -0.254 & -0.291 \\
\hline $3 \mathrm{C} 4 \mathrm{LT}$ & -0.406 & -0.318 & -0.279 & $-0,474$ & -0.445 & -0.435 & -0.426 \\
\hline $3 \mathrm{C5LT}$ & -0.554 & $-0,301$ & -0.488 & -0.503 & -0.410 & -0.507 & -0.493 \\
\hline 3C6IT & -0.590 & -0.420 & -0.405 & -0.547 & -0.495 & -0.419 & -0.512 \\
\hline 3C7LT & -0.463 & -0.254 & -0.427 & -0.311 & -0.297 & -0.259 & -0.368 \\
\hline 3H4LT & +0.094 & +0.308 & +0.163 & +0.084 & +0.065 & $+0: 130$ & +0.108 \\
\hline 3H5LT & +0.036 & +0.098 & +0.072 & +0.058 & +0.008 & $+0,108$ & +0.030 \\
\hline 3H7IT & +0.022 & +0.058 & +0.029 & +0.022 & +0.058 & +0.047 & +0.006 \\
\hline
\end{tabular}




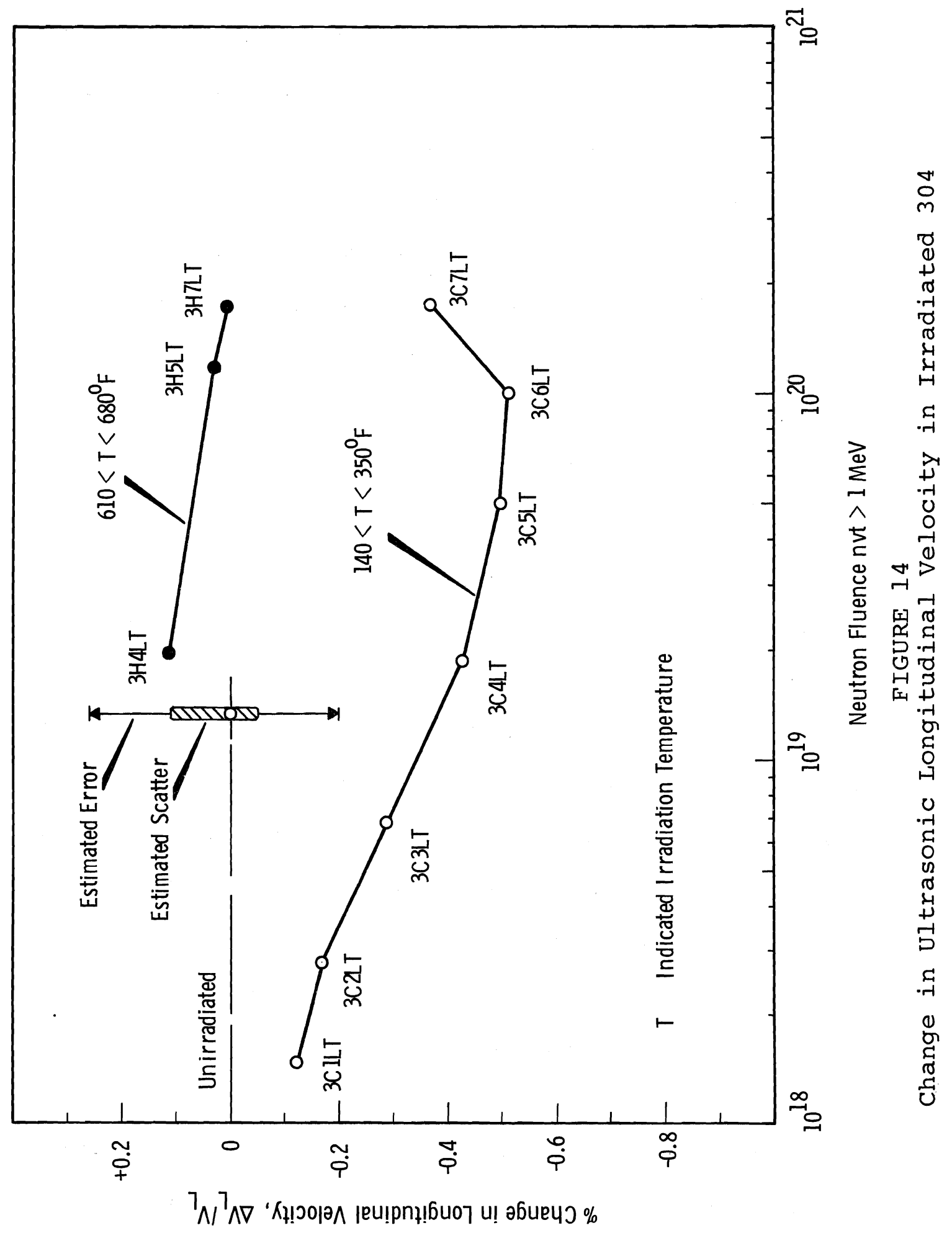


- Change in longitudinal velocity appears to be in the decreasing direction for high temperature reactor irradiations $\left(\mathrm{T} \cong 610^{\circ} \mathrm{F}\right.$ to $\left.680^{\circ} \mathrm{F}\right)$. The position of the high temperature curve suggests the possibility that $V_{L}$ had increased at lower fluences but subsequently reversed direction at some fluence still lower than final dosages used in this study. Magnitude of changes are too small to be reliably isolated from possible scatter and error.

- If a sufficient number of measurements can be made so as to reduce scatter error, the radiation damage on low temperature irradiated 304 can be detected at exposures as low as 4 or 5 $\mathrm{x} 10^{18} \mathrm{nvt}>1 \mathrm{MeV}$.

- The low temperature irradiated specimen at $1.75 \times 10^{20}$ nvt has a velocity change much less than would be expected from the curve's trend.

Additional change-in-longitudinal-velocity measurements were taken on 22 irradiated AISI 304 (annealed) miniature tensile-creep specimens. Irradiation temperatures are estimated to fall within $700^{\circ} \mathrm{F}$ to $1100^{\circ} \mathrm{F}$. Neutron fluences are estimated to fall within $1 \times 10^{19}$ to $1.1 \times 10^{21} \mathrm{nvt}>1 \mathrm{MeV}$ in a fast flux spectrum. Measurements were made using a through-transmission method. The reference specimen was not thermally aged.

Results are shown as a histogram in Figure 15. Changes in velocity ranged from an increase of $0.27 \%$ to a decrease of $0.86 \%$. Two other specimens, which were $25 \%$ cold worked, showed increases 
Estimated I rradiation Temperature: $700^{\circ} \mathrm{F}$ to $1100^{\circ} \mathrm{F}$

Estimated Neutron Fluence: $1 \times 10^{19}$ nvt to $1.1 \times 10^{21}$ nvt

(E > I MeV)

Pre-I rradiated Anneal ed 1 hr @ $1950^{\circ} \mathrm{F}$

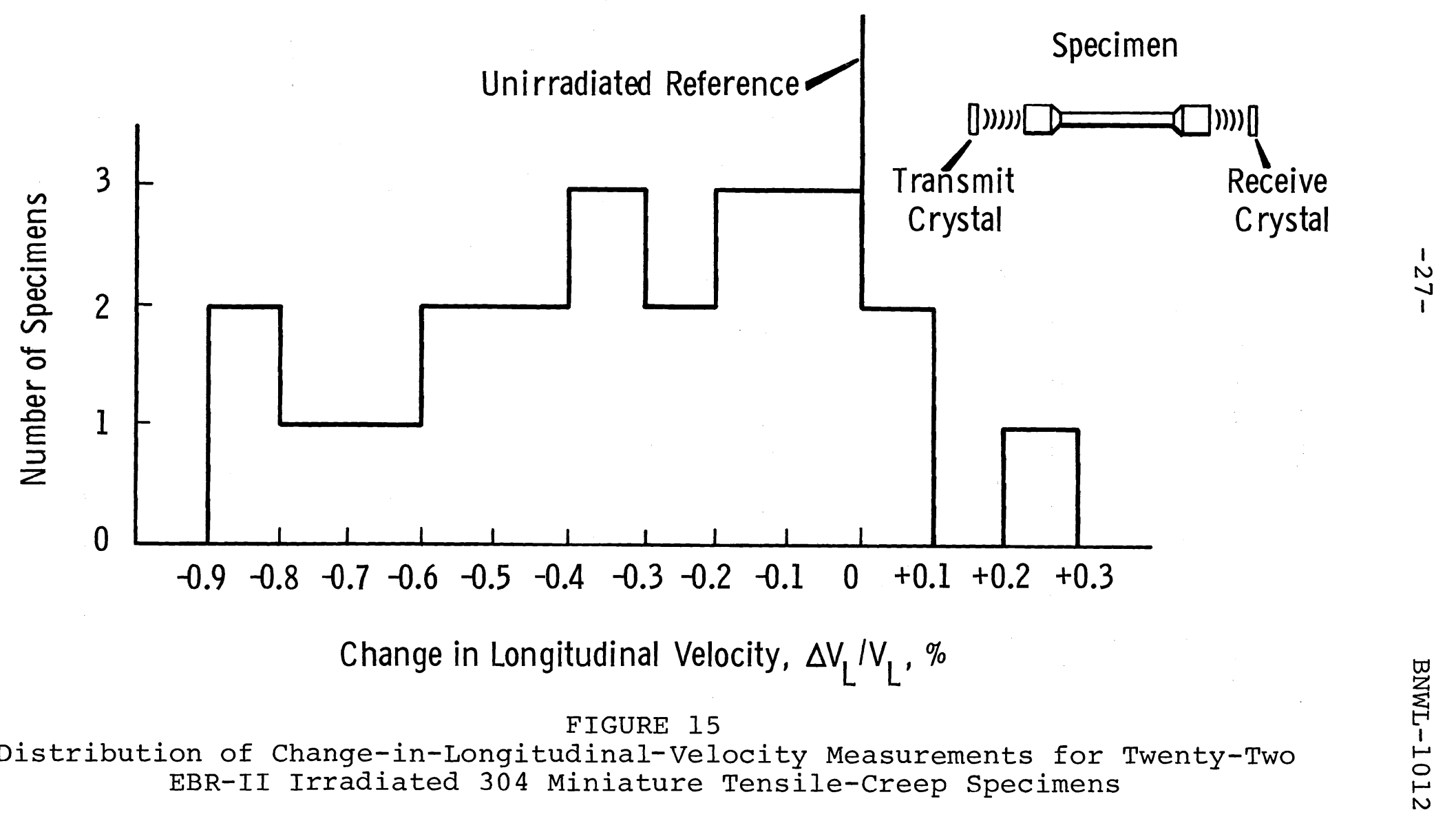


of $0.31 \%$ and $0.73 \%$. The effects of cold-working and high irradiation temperatures undoubtedly have contributed to changes but to what extent remains undetermined.

Measurements on five unirradiated specimens indicate error due to scatter will be at least $0.2 \%$.

Changes in Elastic Properties

Change-in-density data, necessary for approximating the elastic constants changes, are found in Table V. Also tabulated in Table V are specimens' cross-sectional measurements. When compared to measurements taken before irradiation, swelling can be determined subject to error related to the remote micrometer measurement method. Swelling on specimen 3 C6LT averaged 0.0003 in. on a cross section.

The apparent effect of irradiation on elastic properties has been calculated for two specimens, 3C6IT and 3H4LT. Elastic properties for irradiated specimens 3C6LT and 3H4LT are shown in Table VI.

Sample calculations for specimen 3C6LT follow:

- shear modulus is given by $G=\rho V_{S}^{2}$

$$
\begin{aligned}
\text { where } \rho & =\text { density, and } \\
V_{S} & =\text { shear velocity } \\
\Delta G / G=\Delta \rho / \rho+2 \Delta V_{S} / V_{S} &
\end{aligned}
$$$$
\Delta G / G \cong-0.0023+2(-0.0126) \cong-2.75 \%
$$

- bulk modulus is given by $\mathrm{K}=\rho \mathrm{V}_{\mathrm{L}}^{2}-4 / 3 \mathrm{~V}_{\mathrm{S}}^{2}$

$$
\text { where } \mathrm{V}_{\mathrm{L}}=\text { longitudinal velocity }
$$




\section{TABLE V}

SWELLING AND CHANGE IN DENSITY,

IRRADIATED 304

\begin{tabular}{|c|c|c|c|c|c|}
\hline $\begin{array}{l}\text { Specimen } \\
\text { Identi- } \\
\text { fication }\end{array}$ & $\begin{array}{l}\text { Rounded } \\
\text { Average } \\
\text { Dimension } \\
\text { Pos. } 1 \& 4, \\
\text { in. } \times 10^{-3} \\
\end{array}$ & $\begin{array}{l}\text { Rounded } \\
\text { Average } \\
\text { Dimension } \\
\text { Pos. } 285, \\
\text { in. } \times 10^{-3}\end{array}$ & $\begin{array}{l}\text { Rounded } \\
\text { Average } \\
\text { Dimension } \\
\text { Pos. } 386, \\
\text { in. } \times 10^{-3} \\
\end{array}$ & $\begin{array}{l}\text { Corrected } \\
\text { Average } \\
\text { Swelling } \\
\text { Pos. } 1-6, \\
\text { in. } \times 10^{-3} \\
\end{array}$ & $\begin{array}{l}\text { Change } \\
\text { in } \\
\text { Density, } \\
\triangle \rho / \rho, \\
\% \\
\end{array}$ \\
\hline $3 \mathrm{C} 1 \mathrm{LT}$ & 394.0 & 394.1 & 393.8 & 0.08 & -0.06 \\
\hline $3 \mathrm{C} 2 \mathrm{LT}$ & 393.9 & 394.2 & 394.1 & 0.20 & -0.15 \\
\hline $3 C 3 L T$ & 394.6 & 394.9 & 394.5 & 0.30 & -0.23 \\
\hline $3 C 4 L T$ & 394.6 & 394.5 & 394.4 & 0.16 & -0.12 \\
\hline $3 \mathrm{C} 5 \mathrm{LT}$ & 394.6 & 394.7 & 394.6 & 0.31 & -0.23 \\
\hline $3 \mathrm{C} 6 \mathrm{LT}$ & 394.5 & 394.6 & 394.8 & 0.30 & -0.23 \\
\hline $3 C 7 L T$ & 394.4 & 394.4 & 394.8 & 0.40 & -0.30 \\
\hline 3H4LT & 393.6 & 393.9 & 394.0 & 0.08 & -0.06 \\
\hline 3H5LT & 394.5 & 394.2 & 394.3 & 0.10 & -0.07 \\
\hline 3H7LT & 394.5 & 394.0 & 394.3 & 0 & 0 \\
\hline $\begin{array}{l}\text { 3UOLT } \\
\text { (Unirr- } \\
\text { adiated) }\end{array}$ & 394.5 & 394.3 & 394.4 & & \\
\hline
\end{tabular}




\section{TABLE VI}

ELASTIC PROPERTIES FOR UNIRRADIATED 304 STEEL,

AND APPARENT CHANGES IN ELASTIC PROPERTIES

FOR TWO IRRADIATED 304 SPECIMENS

\section{Property}

Shear Velocity, $V_{S}, \mathrm{~cm} / \mathrm{sec} \times 10^{5}$

Longitudinal Velocity, $V_{L}, \mathrm{~cm} / \mathrm{sec} \times 10^{5}$

Density, $\rho, \mathrm{gm} / \mathrm{cm}^{3}$

Shear Modulus, G, dynes $/ \mathrm{cm}^{2} \times 10^{11}$

Bulk Modulus, $\mathrm{K}$, dynes $/ \mathrm{cm}^{2} \times 10^{11}$

Poisson's Ratio, $\sigma$

Young's Modulus, E, dynes $/ \mathrm{cm}^{2} \times 10^{11}$

$\triangle V_{\mathrm{S}}, \mathrm{cm} / \mathrm{sec} \times 10^{5}$

$\triangle \mathrm{V}_{\mathrm{S}} / \mathrm{V}_{\mathrm{S}}, \%$

$\Delta \mathrm{V}_{\mathrm{L}}, \mathrm{cm} / \mathrm{sec} \times 10^{5}$

$\Delta \mathrm{V}_{\mathrm{L}} / \mathrm{V}_{\mathrm{L}}, \%$

$\triangle \rho, \mathrm{gm} / \mathrm{cm}^{3}$

$\triangle p / \rho, \%$

$\triangle \mathrm{G}$, dynes $/ \mathrm{cm}^{2} \times 10^{11}$

$\triangle G / G, \%$

$\Delta \mathrm{K}$, dynes $/ \mathrm{cm}^{2} \times 10^{11}$

$\Delta \mathrm{K} / \mathrm{K}, \%$

$\Delta \sigma$

$\Delta \sigma / \sigma, \%$

$\Delta \mathrm{E}$, dynes $/ \mathrm{cm}^{2} \times 10^{11}$

$\triangle \mathrm{E} / \mathrm{E}, \%$

\begin{tabular}{lll}
$\begin{array}{lll}\text { Specimen } \\
\text { 3C6LT }\end{array}$ & & $\begin{array}{l}\text { Specimen } \\
\text { 3H4LT }\end{array}$ \\
\cline { 1 - 1 } 3.14 & & 3.14 \\
5.74 & & 5.74 \\
7.93 & & 7.93 \\
7.81 & & 7.81 \\
15.70 & & 15.70 \\
0.286 & & 0.286 \\
20.10 & & 20.10 \\
-0.040 & & -0.007 \\
-1.26 & & +0.23 \\
-0.030 & & -0.006 \\
-0.51 & & +0.11 \\
-0.018 & & -0.005 \\
-0.23 & & -0.06 \\
-0.215 & & +0.031 \\
-2.75 & & +0.40 \\
-0.032 & & -0.017 \\
-0.26 & & -0.11 \\
+0.0045 & +0.0007 \\
+1.58 & & +0.26 \\
-0.483 & & -0.094 \\
-2.4 & & -0.47 \\
& &
\end{tabular}




$$
\begin{aligned}
& \frac{\Delta K}{\bar{K}}=\frac{\Delta \rho}{\rho}+2 \frac{V_{L} \Delta V_{L}}{V_{L}^{2}-4 / 3 V_{S}^{2}}-\frac{8}{3} \frac{V_{S} \Delta V_{S}}{V_{L}^{2}-4 / 3 V_{S}^{2}} \\
& \Delta K / K=\Delta \rho / \rho+\Delta V_{L}\left(0.578 \times 10^{-5}\right)-\Delta V_{S}\left(0.422 \times 10^{-5}\right) \\
& \Delta K / K \cong-0.0023-0.017+0.0167 \cong-0.26 \%
\end{aligned}
$$

- Poisson's ratio is given by $\sigma=\frac{V_{L}{ }^{2}-2 V_{S}^{2}}{2\left(V_{L}{ }^{2}-V_{S}{ }^{2}\right)}$

$$
\frac{\Delta \sigma}{\sigma}=\frac{2 V_{S} V_{L}}{\left(V_{L}^{2}-2 V_{S}^{2}\right)\left(V_{L}^{2}-V_{S}^{2}\right)}\left(V_{S} \Delta V_{L}-V_{L} \Delta V_{S}\right)
$$

$\Delta \sigma / \sigma=0.367 \times 10^{-5} \Delta V_{L}-0.672 \times 10^{-5} \Delta V_{S}$

$\Delta \sigma / \sigma \cong-0.0108+0.0266 \cong+1.58 \%$

- Young's modulus is given by $E=V_{S}{ }^{2} \frac{3 V_{L}^{2}-4 V_{S}^{2}}{V_{L}^{2}-V_{S}^{2}}$

$$
\begin{aligned}
& \frac{\Delta \mathrm{E}}{\mathrm{E}}=\frac{\Delta \rho}{\rho}-\left[\frac{{ }^{2 \mathrm{~V}_{S} \mathrm{~V}_{L}^{2}}}{\left(\mathrm{~V}_{\mathrm{L}}{ }^{2}-\mathrm{V}_{\mathrm{S}}{ }^{2}\right)\left(3 \mathrm{~V}_{\mathrm{L}}{ }^{2}-4 \mathrm{~V}_{\mathrm{S}}{ }^{2}\right)}-\frac{2}{\mathrm{~V}_{\mathrm{S}}}\right] \Delta \mathrm{V}_{\mathrm{S}}{ }^{+} \\
& {\left[\frac{2 \mathrm{~V}_{\mathrm{L}} \mathrm{V}_{\mathrm{S}}^{2}}{\left(\mathrm{~V}_{\mathrm{L}}{ }^{2}-\mathrm{V}_{\mathrm{S}}{ }^{2}\right)\left(3 \mathrm{~V}_{\mathrm{L}}{ }^{2}-4 \mathrm{~V}_{\mathrm{S}}{ }^{2}\right)}\right] \Delta \mathrm{V}_{\mathrm{L}}} \\
& \Delta \mathrm{E} / \mathrm{E}=\Delta \rho / \rho+\Delta \mathrm{V}_{\mathrm{S}}\left(0.488 \times 10^{-5}\right)+\Delta \mathrm{V}_{\mathrm{L}}\left(0.082 \times 10^{-5}\right) \\
& \Delta \mathrm{E} / \mathrm{E} \cong-0.0023-0.0193-0.0024 \cong-2.4 \%
\end{aligned}
$$

Changes in Critical-Angle-Method Signal Amplitude

A tabulation of measurements is shown in Table VII. A final data point for a specimen is the average of several RF amplitude measurements and several integrated-scan measurements. Normalizing 
TABLE-VII

CHANGE IN CRITICAL ANGLE SIGNAL AMPLITUDE IN IRRADIATED 304

\begin{tabular}{|c|c|c|c|c|c|c|c|}
\hline $\begin{array}{l}\text { Specimen } \\
\text { Identi- } \\
\text { fication }\end{array}$ & $\begin{array}{l}\text { Average } \\
\text { of Four } \\
\text { RF Meas- } \\
\text { urements } \\
\text { Sides } \\
183, \\
\mathrm{v}_{1}\end{array}$ & $\begin{array}{l}\text { Average } \\
\text { of Four } \\
\text { Integra- } \\
\text { ted Scans } \\
\quad \text { Sides } \\
1,2,3,4 \\
v_{2}\end{array}$ & $\begin{array}{c}\text { Average } \\
\text { of Two } \\
\text { Integra- } \\
\text { ted Scans } \\
\text { Sides } \\
1 \& 3 \\
v_{3}\end{array}$ & $\begin{array}{l}\text { Normal- } \\
\text { ized Ave. } \\
\text { of Four } \\
\text { RF Msmts. } \\
\left(\begin{array}{l}\text { x } 4) \text {, } \\
\Delta A_{1}\end{array}\right.\end{array}$ & $\begin{array}{l}\text { Normal- } \\
\text { ized Ave. } \\
\text { of Four } \\
\text { Int. Scans } \\
\left(x \frac{71.12}{5.65}\right), \\
\Delta A_{2}\end{array}$ & $\begin{array}{l}\text { Normal- } \\
\text { ized Ave. } \\
\text { of Two } \\
\text { Int. Scans } \\
\left(x \frac{71.12}{25.96}\right) \text {, } \\
\Delta A_{3}\end{array}$ & $\begin{array}{l}\text { Weighted } \\
\text { Ave. of } \\
\triangle \mathrm{A}_{1}, \Delta \mathrm{A}_{2}, \\
\& \mathrm{AA}_{3}, \\
\triangle \mathrm{A}_{\mathrm{CA}}\end{array}$ \\
\hline $3 \mathrm{C} 1 \mathrm{LT}$ & 1.52 & 0.70 & 2.89 & 6.08 & 8.82 & 7.94 & $7 \cdot 92$ \\
\hline $3 \mathrm{C} 2 \mathrm{LT}$ & 3.50 & 1.24 & 5.80 & 14.00 & 17.65 & 15.95 & 16.32 \\
\hline $3 C 3 \mathrm{LT}$ & 10.60 & 3.06 & 13.46 & 42.40 & 38.60 & 37.00 & 39.15 \\
\hline $3 \mathrm{C} 4 \mathrm{LT}$ & $12 \cdot 90$ & $4 \cdot 32$ & 20.86 & 51.60 & 54.30 & 57.26 & 54.37 \\
\hline $305 \mathrm{LT}$ & 16.92 & 5.62 & 23.96 & 67.68 & 71.00 & 65.80 & 68.87 \\
\hline $3 \mathrm{C} 6 \mathrm{LT}$ & 19.02 & 6.22 & 28.16 & 76.08 & 78.30 & 77.10 & 77.45 \\
\hline $307 \mathrm{LT}$ & 17.78 & 5.65 & 25.96 & 71.12 & 71.12 & 71.12 & 71.12 \\
\hline $3 \mathrm{H} 4 \mathrm{LT}$ & -3.20 & -0.87 & -4.09 & -12.80 & -11.00 & $-11 \cdot 24$ & $-11 \cdot 51$ \\
\hline 3H5LT & $2 \cdot 28$ & 0.21 & 1.06 & 9.12 & 2.65 & 2.91 & $4 \cdot 34$ \\
\hline 3H7LT & -2.85 & -0.70 & -3.47 & -11.40 & -8.32 & -9.52 & -9.64 \\
\hline
\end{tabular}


is performed to make the several measurements compatible with each other. Final data points are plotted in Figure 16.

From the curves in Figure 16, the following observations are noted:

- Neutron irradiation has caused an increase in critical-anglemethod signal $\triangle \mathrm{A}_{\mathrm{CA}}$ in the approximate amount of 35 (arbitrary units) per decade in the range of $10^{18}$ nvt to $2 \times 10^{20} \mathrm{nvt}$ $(>1 \mathrm{MeV})$ for low temperature reactor irradiations $\left(\mathrm{T} \cong 140^{\circ} \mathrm{F}\right.$ to $350^{\circ} \mathrm{F}$ ). Ignoring anomalies, the relationship may be expressed as follows:

$$
\begin{aligned}
\Delta \mathrm{A}_{\mathrm{CA}} \cong \Delta \mathrm{A}_{\mathrm{CA}}^{\prime}+35 \log \phi t / 10^{18} \\
\text { where } \Delta \mathrm{A}_{\mathrm{CA}}^{\prime} \cong 5 \text { (arbitrary units), and } \\
\phi t=\text { neutron fluence }>1 \mathrm{MeV} .
\end{aligned}
$$

"Change in critical-angle-method signal amplitude appears to be in the increasing direction for high temperature reactor irradiations $\left(\mathrm{T} \cong 610^{\circ} \mathrm{F}\right.$ to $\left.680^{\circ} \mathrm{F}\right)$. Changes may have been in the opposite direction at lower fluences than used in this study:

- If a sufficient number of measurements can be made so as to reduce scatter error, the radiation damage on low temperature irradiated 304 can be detected at exposures as low as about $2 \times 10^{18}$ nvt $>1 \mathrm{MeV}$.

- Specimens receiving the highest exposure, for both high and low temperature irradiated groups, have changes less than 


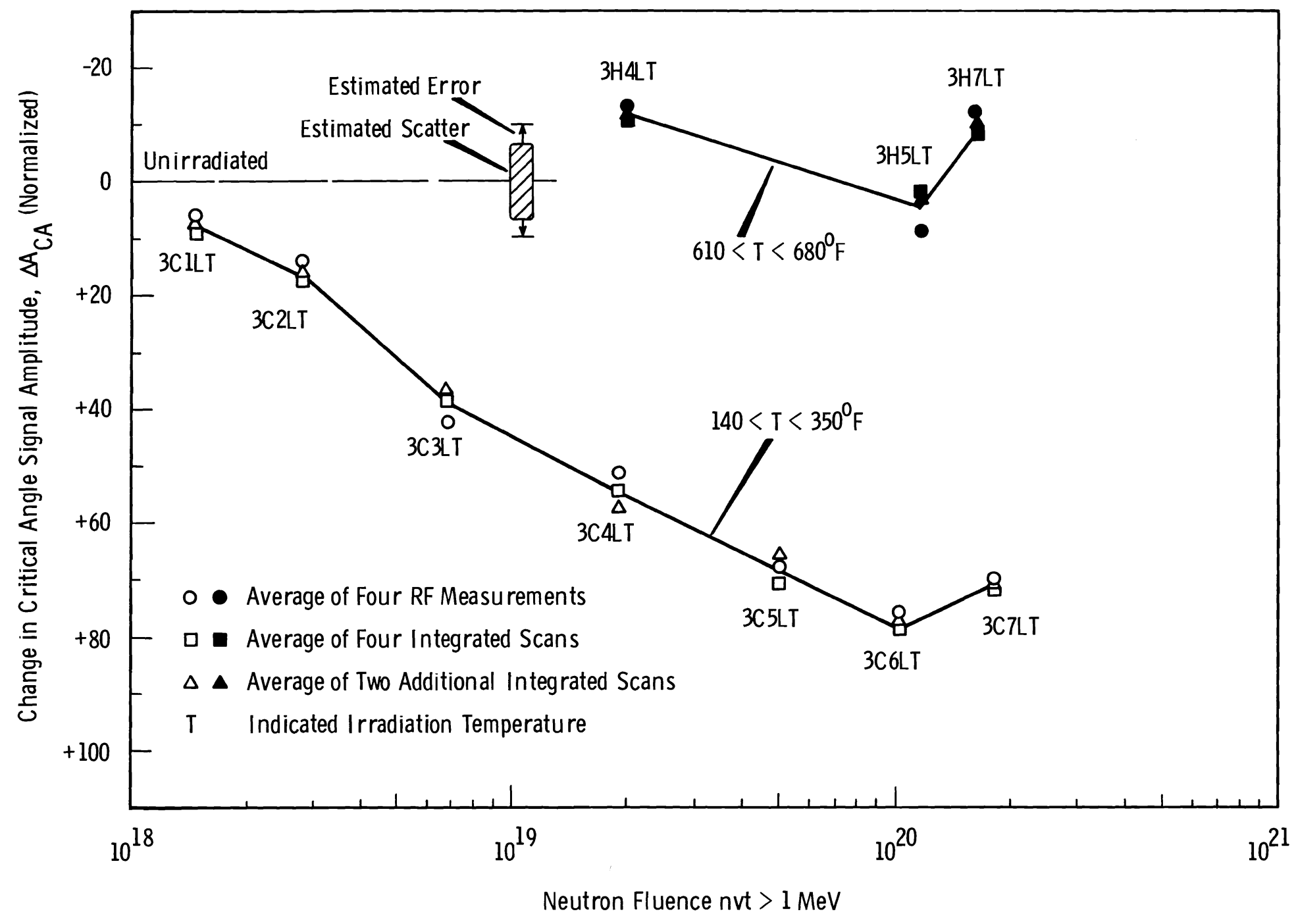

FIGURE 16

Change in Ultrasonic Critical-Angle-Method Signal Amplitude for Irradiated 304 
would be expected from their curves' trends.

\section{$\underline{\text { Scatter and Error }}$}

Scatter is defined as a possible variation in the measured ultrasonic property due to material property variations existing before irradiation. Measurements were not taken before irradiation. Scatter was determined from measurements taken on unirradiated control specimens. Some control specimens were thermally aged for a three week period: one each at temperatures from $200^{\circ} \mathrm{F}$ through $800^{\circ} \mathrm{F}$ in $100^{\circ} \mathrm{F}$ increments. Velocities and critical-angle-method changes due to thermal aging were judged to be negligible. See Table VIII for a listing of measurements taken on control specimens. Scatter was exceptionally severe in the 304 specimens, much more severe than in the low alloy steel specimens. (3) Scatter was so severe in the 304 specimens as to render single position measurements largely meaningless. Several measurements were necessary per specimen to obtain the curves shown in this report. Measurements taken on control specimens determined how much correction should be given each measurement as an allowance for the reference specimen, 3UOLT, not being an average representation for all the control specimens, Shear velocity measurements were individually corrected depending on the measurements taken on control specimens which came from donor plate positions adjacent to those of the irradiated specimens. Longitudinal velocity measurements on irradiated specimens were each given the same correction $1+0.033 \%$ 


\section{TABLE-VIII}

CHANGES IN SHEAR VELOCITY, LONGITUDINAL VELOCITY, AND

CRITICAL ANGLE SIGNAL AMPLITUDE FOR 304

CONTROL SPECIMENS

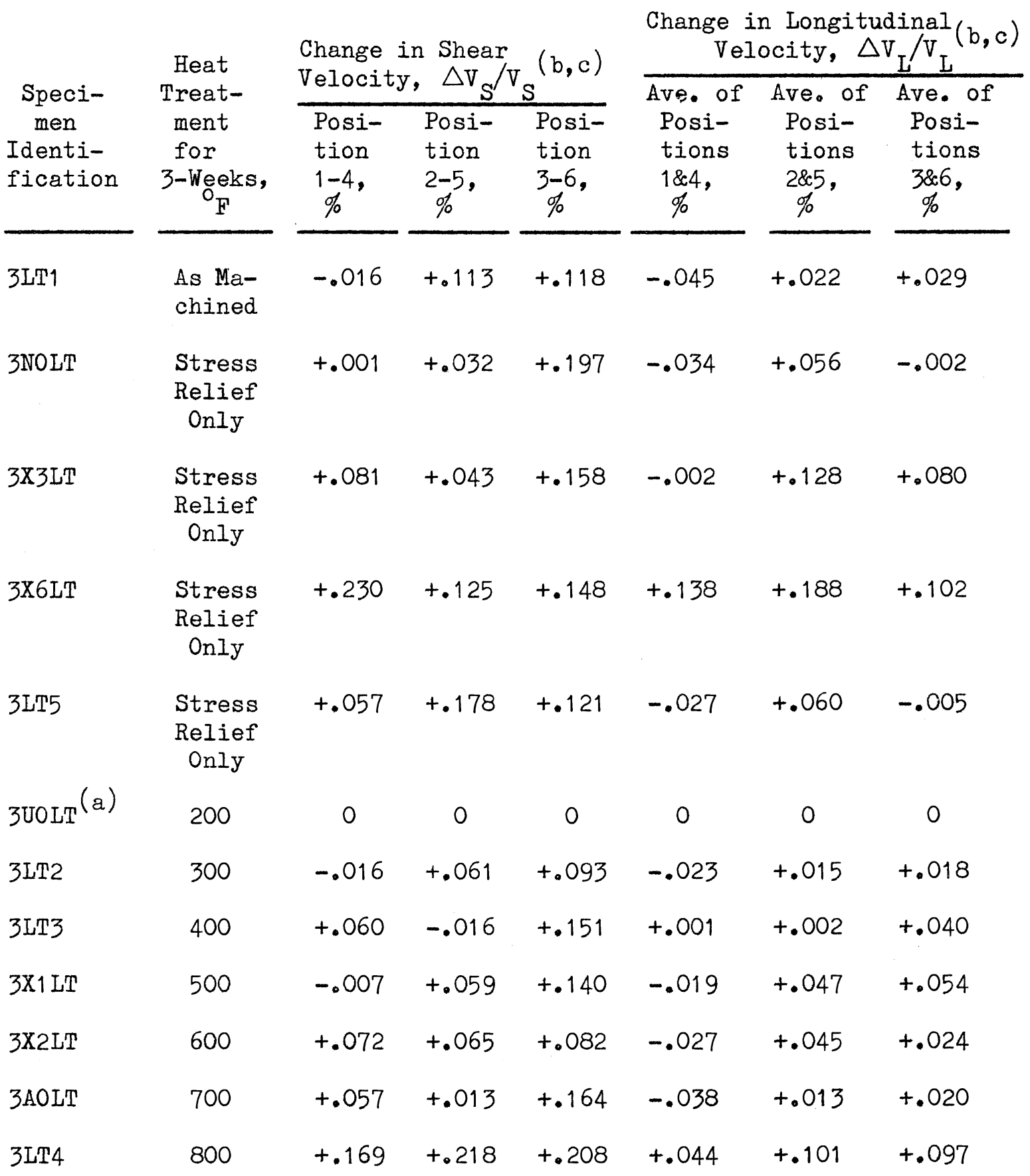


TABIE VIII (Continued)

\begin{tabular}{|c|c|c|c|}
\hline \multirow[b]{2}{*}{$\begin{array}{l}\text { Specimen } \\
\text { Identi- } \\
\text { fication }\end{array}$} & \multicolumn{3}{|c|}{ Critical Angle Signal Amplitude, $\triangle A_{C A}(b, c, d)$} \\
\hline & $\begin{array}{l}\text { Average of } \\
\text { Eight RF } \\
\text { Measurements, } \\
\qquad \mathrm{v}_{1}\end{array}$ & $\begin{array}{l}\text { Average of } \\
\text { Four Integ- } \\
\text { rated Scans, } \\
\qquad \mathrm{v}_{2}\end{array}$ & $\begin{array}{c}\text { Normalized } \\
\text { \& Weighted } \\
\text { Ave。 of } v_{1} \& v_{2} \\
\left(x \frac{71.12}{5.65}\right)^{2} \\
\triangle A_{C A}\end{array}$ \\
\hline 3LT1 & +0.285 & +0.266 & +3.43 \\
\hline 3NOLT & +0.110 & +0.090 & +1.22 \\
\hline 3X3LT & -0.130 & & -1.64 \\
\hline $3 \mathrm{XIT}$ & +0.172 & & +2.16 \\
\hline 3LT5 & +0.180 & & +2.26 \\
\hline 3UOLT $(a)$ & 0 & 0 & 0 \\
\hline 3LT2 & -0.365 & -0.300 & -4.05 \\
\hline 3LT3 & -0.255 & -0.305 & -3.63 \\
\hline $3 \mathrm{X} 1 \mathrm{LT}$ & +0.530 & +0.509 & +6.50 \\
\hline $3 X 2 L T$ & -0.252 & +0.032 & -0.79 \\
\hline 3AOLT & -0.155 & -0.242 & -2.69 \\
\hline 3 LT4 & -0.135 & -0.709 & -6.51 \\
\hline
\end{tabular}

Notes: (a) Specimen 3UOLT used as reference for all measurements.

(b) A + reading designates an increase in velocity or signal amplitude relative to the same measurement at a similar position on 3UOIT.

(c) A - reading designates a decrease in velocity or signal amplitude relative to the same measurement at a similar position on 3UOLT.

(d) $v_{1}, v_{2},=$ arbitrary units of voltage amplitude. 
subtracted from the average of six readings for each specimen). No corrections were given critical-angle-method measurements.

Measurements on the control specimens also determined scatter limits. Those control specimens which had the greatest deviation in the positive and in the negative directions relative to the reference specimen, 3UOLT, determined the scatter limits.

Error was determined through a series of repetitive measurements, both micrometer measurements of specimen cross-section dimensions and ultrasonic measurements. An additional error contribution was allowed for method, water temperature variations, etc. Errors are: $\Delta \mathrm{V}_{\mathrm{S}} / \mathrm{V}_{\mathrm{S}}= \pm 0.1 \%, \Delta \mathrm{V}_{\mathrm{L}} / \mathrm{V}_{\mathrm{L}}= \pm 0.15 \%, \Delta \mathrm{A}_{\mathrm{CA}}= \pm 2.4$ (normalized scale).

\section{DISCUSSION}

\section{General}

A trend for decreasing ultrasonic propagation velocities has been shown fo exist as a function of increasing neutron fluence. The critical-angle-method curves are seen to approximate the shapes of the $\Delta V$ curves. Changes in velocity are the probable cause of the changes in critical angle signal although changes in density and attenuation will also contribute.

Changes in velocity relate to changes in elastic properties through the equations of motion in an elastic medium. Irradiated 304 can only approximately be considered as an isotropic, homogeneous, elastic material. Consequently, the results given in the previous section must also be approximate and useful more as an indication 
of trends rather than as absolute quantities.

The measured changes are approximately double the changes measured on low alloy steels for identical temperatures and neutron fluences。 (3) Causes of the larger changes in 304 are undetermined although, in addition to composition and atomic crystalline structure differences, it is noted that 304 had been solution annealed prior to irradiation whereas the low alloy steels had been quenched and tempered.

Shapes of 304 and low alloy steel curves are about the same with some exceptions. The most notable difference is the absence of a reduction in slope in the $\mathrm{C} 4$ to $\mathrm{C} 5$ specimens region for 304. Another difference appears on the $304 \mathrm{H} 7$ data point for $\Delta \mathrm{A}_{\mathrm{CA}}$, a data point displaced unexpectedly far in the increased velocity direction. Some of the differences in curve shapes, again, probably relate to the metallurgical differences between the steels.

Cause of the anomalous $\Delta \mathrm{A}_{\mathrm{CA}}$ data point for $3 \mathrm{H} 7 \mathrm{LT}$ is undetermined. It need not be surprising that the $\triangle A_{C A}$ curves are somewhat different from the $\Delta V$ curves, however, since the critical-angle method measures changes in surface properties whereas the $\Delta V$ methods measure changes in properties extending through most of the specimen's cross section. Effects of Irradiation Temperature

A listing of irradiation temperatures is seen in Table II. It is seen that calculated temperatures jumped sharply starting 
with the $\mathrm{C} 5$ specimen relative to the $\mathrm{C} 4$ specimen; and a further increase was seen by the $\mathrm{C} 7$ specimen relative to the $\mathrm{C} 6$ specimen. Although the increased temperatures are the apparent cause of the changed trend of $\Delta V$ measurements for the low alloy steel $C_{5}$

specimens, ${ }^{(3)}$ the $\Delta V$ measurements for 304 remained on a smooth trend curve. Irradiation damage in 304 steel is apparently not quite as sensitive to irradiation temperature as it is in A302-B or A542-B - at least up to the C7 specimen's temperatures, about $285^{\circ} \mathrm{F}$ to $376^{\circ} \mathrm{F}$ 。

The $\mathrm{C} 7$ specimen was affected for 304 in a manner similar to that of the low alloy steels. A significantly higher irradiation temperature for the $\mathrm{C} 7$ specimens relative to the $\mathrm{C} 6$ specimens is the probable cause of the change in trend from $\mathrm{C} 6$ to $\mathrm{C} 7$.

The three specimens irradiated at high temperatures are much less affected than are the seven specimens irradiated at low temperatures. Apparently, damage recovery is accelerated at some temperature lying between about $300^{\circ} \mathrm{F}$ and $680^{\circ} \mathrm{F}$. Whether recovery occurs somewhat linearly as a function of temperature or in jumps has not been determined during this study。

Measurements on thermally aged control specimens (see Table VIII) showed little change in velocities as a function of temperature only. The combined effects of temperature and irradiation, however, are not too well defined. The increased velocities in some high temperature irradiated specimens could be primarily as a result of 
heating rather than irradiation. On the other hand, the increased velocities could also be as a result of thermally activated irradiation damage recovery mechanisms affecting one contributor to elastic properties changes but not affecting another opposing contributor. Effects of Variation in Neutron Energy Spectrum

As seen in Table I, the $\mathrm{C} 5, \mathrm{C} 6, \mathrm{C} 7, \mathrm{H} 4, \mathrm{H} 5$, and $\mathrm{H} 7$ specimens all were irradiated in a "harder" neutron energy spectrum than were the $\mathrm{C} 1, \mathrm{C} 2, \mathrm{C} 3$, and C4 specimens. A slight reduction in slope of the low temperature $\Delta \mathrm{V} \& \Delta \mathrm{A}_{\mathrm{CA}}$ curves could feasibly be partly as a result of the low thermal/fast neutrons ratio for the $\mathrm{C} 5, \mathrm{C} 6$, and C7 specimens. In other words, there may be a noticeable contribution to damage, as measured by ultrasonic $\Delta V$ methods, from lower energy (less than $1 \mathrm{MeV}$ ) neutrons bombardment. Much of the mechanical damage to austenitic steels is thought to result from low energy neutron bombardment; capture of thermal neutrons by some elements results in gas generation and accumulation which tends to be more severe at grain boundaries. $(6,7)$ It appears more likely, however, for the work described herein, that the detected damage is as a consequence of atomic displacements rather than transmutations as the gas concentration is quite low and not apt to significantly affect elastic properties. Causes of Changes in Velocities

Several mechanisms are thought to contribute to elastic properties changes. One of them, the dislocations density and 
and damping mechanism first described at megahertz frequencies by Granato and Lücke, $(8,9)$ stands apart from the others. Under this mechanism, velocities might be expected to first increase due to radiation defects interactions with dislocations, then decrease as dislocation density increases at higher fluences due to collapse of clusters of defects, and then once again to increase as dislocations become so dense as to interact with each other.

Other mechanisms seem to be related to each other. Included are effects on elastic constants due to:

- interstitials and vacancies, calculated by Dienes using an interatomic potential energy approach; (10)

- spherical holes, one treatment of which has been done by MacKenzie using classical elasticity theory; ${ }^{(11)}$ and - multiple scatterers, as described by Truell and colleagues. $(12,13)$ Although some conflicting effects might be predicted, in general one would expect reduced velocities if reduced-atomic-density zones predominated over increased-atomic-density zones. Reduced-atomicdensity zones might predominate at the temperatures used in this study where interstitials are more mobile than their vacancy counterparts $(14)$ and hence more likely to anneal-out to some location where their presence would be relatively unfelt such as at grain boundaries, surfaces, and other sinks。 Relationship of Changes in Ultrasonic Velocities to Change in Ductility

Ultrasonic methods appear to be feasible for detection of 
radiation damage at lower irradiation temperatures. As shown in Figure 17, changes in $\Delta V_{S}$ (or $\Delta V_{L}$ or $\Delta A_{C A}$ ) appears indirectly correlative to degraded ductility as measured by total elongation. At higher irradiation temperatures, however, ultrasonic changes become less, but degraded ductility becomes greater. Other measurements, as shown in Figure 15, indicated there may be significant velocity changes at irradiation temperatures higher than used in this study。 Higher accuracy measurements, such as would result if pre-irradiation measurements are taken, will be necessary to determine effectiveness of ultrasonic measurements of high temperature irradiation damage. In addition, the effects of high temperature thermal aging on ultrasonic velocities should be determined for higher temperatures and longer periods than those shown in Table VIII. Suggested Applications

Ultrasonic methods appear feasible for assessment of atomic displacements related damage in low temperature irradiated austenitic steels. If irradiated at higher temperatures or if annealing takes place after irradiation, accurate damage assessment may be possible only when pre-irradiation measurements are taken such as might be done on surveillance specimens. Due to a high sensitivity to temperature as an irradiation parameter, ultrasonic methods appear to be useful for laboratory studies on radiation damage and recovery. 


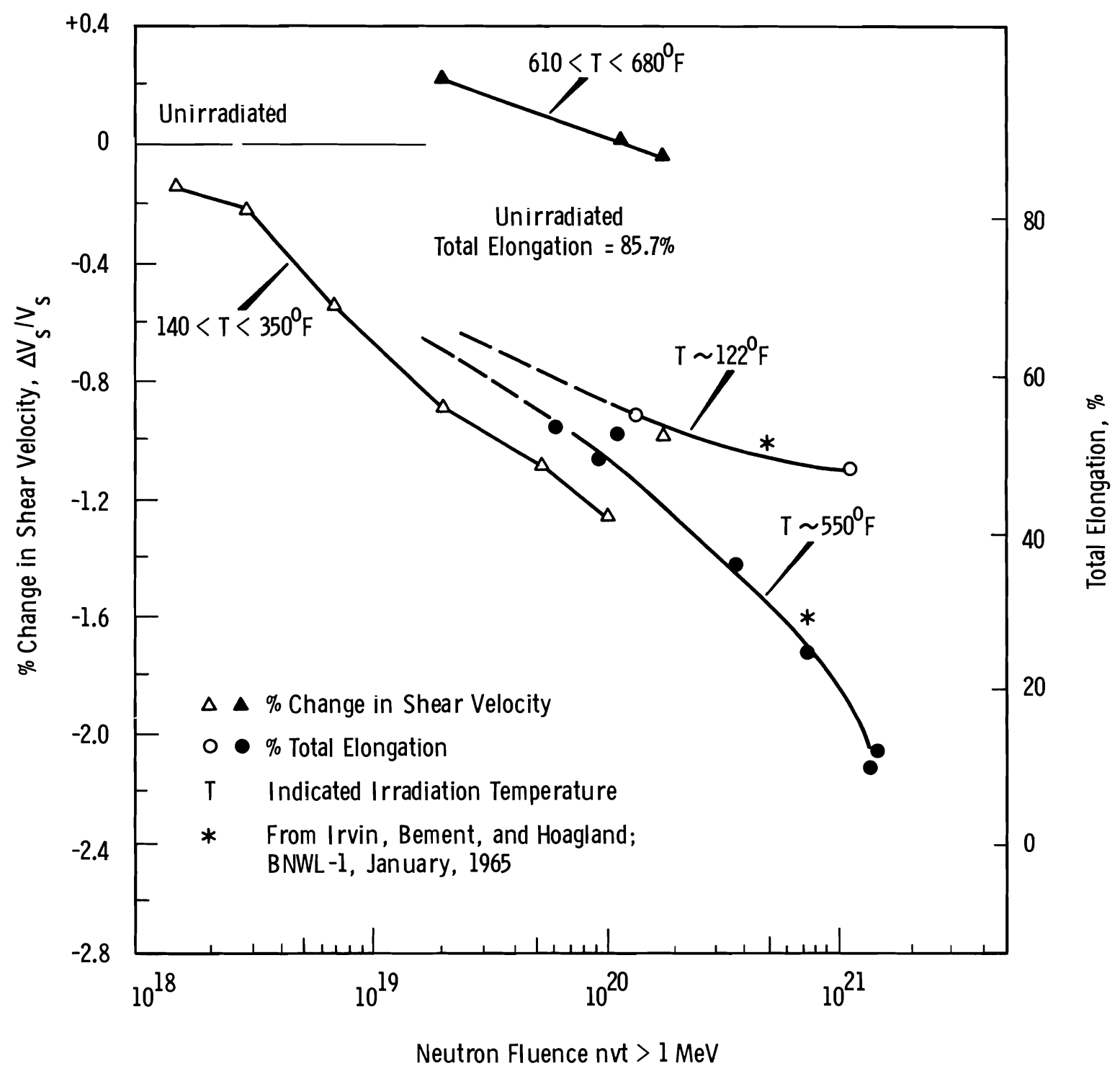

FIGURE 17

Effects of Neutron Irradiation on Ultrasonic Shear Velocity and on Room Temperature Ductility for Annealed 304 Steel 


\section{ACKNOWLEDGEMENTS}

The work described in this report was done under the sponsorship of Fuels and Materials Branch of the USAEC Division of Reactor Development and Technology。

Numerous helpful comments by several Pacific Northwest Laboratory staff members are gratefully acknowledged. Also acknowledged are the services of C. E. Christensen, PNL, NDT Methods Development, who did most of the specimens handling and measurements, and developed part of the electronic instrumentation used during the study.

\section{REFERENCES}

1. J. E. Irvin, A. L。 Bement, and R. G. Hoagland。 The Combined Effects of Temperature and Irradiation On the Mechanical Properties of Austenitic Stainless Steels, BNWL - 1. Pacific Northwest Laboratory, Richland, Washington, January, 1965.

2. J. E. Irvin and A. I. Bement。 "Nature of Radiation Damage to Engineering Properties of Various Stainless Steel Alloys", The Effects of Radiation On Structural Metals, an ASTM Symposium, Atlantic City, No Jo, June 26 - July 1, 1966, ASTM STP No. 426, p. 278, December, 1967。

3. D. 0. Hunter. Ultrasonic Velocities and Critical-Angle-Method Changes in Irradiated A302-B and A542-B Steels, BNWL - 988. Pacific Northwest Laboratory, Richland, Washington, April, 1969.

4. A. Schoch. "Lateral Displacement of a Totally Reflected Ultrasonic Wave Beam", Acustica, Vol。2-1, p. 18-19, 1952.

5. C. E. Fitch, Jro and B. W. Chettle. Critical Angle Ultrasonic Tests, HW-79928. General Electric Co., December, 1963. 
6. G。H.Broomfield, D。R。 Harries, and A。C。Roberts. "Neutron Irradiation Effects in Austenitic Stainless Steels and a Nimonic Alloy", Journal of the Iron and Steel Institute, p. 502, May, 1965。

7. A. L。 Bement. Effects of Minor Constituents on Irradiation Damage to Austenitic Stainless Steels, from an ASTM Meeting Atlantic City, NoJ., June $26-$ July 1, 1966, ASTM STP No. 418, July, 1967。

8. A. Granato and $\mathrm{K}$. Lïcke. "Theory of Mechanical Damping Due to Dislocations", Journal of Applied Physics, vol. 27-6, p. 583, June, 1956.

9. A。 Granato and K. Lïcke. "Application of Dislocation Theory to Internal Friction Phenomena at High Frequencies", Journal of Applied Physics, vol.27-7, p. 789, July, 1956。

10. G. J。 Dienes. "A Theoretical Estimate of the Effect of Radiation on the Elastic Constants of Simple Metals", Physical Review, vol. 86-2, p. 228, April, 1952; also, Physical Review, vol. 87-4, p. 665, August, 1952.

11. J. Ko MacKenzie. "The Elastic Constants of a Solid Containing Spherical Holes", Proceedings of the Physical Society of London, vol.63-B, p. 2, January, 1950。

12. Ro Truell, L。 J。 Teutonico, and P. W. Levy. "Detection of Directional Neutron Damage in Silicon by Means of Ultrasonic Double Refraction Measurements", Physical Review, vol。105-6, p. 1723, March, 1957。

13. R. Truell. "Nature of Defects Arising from Fast Neutron Irradiation of Silicon Single Crystals", Physical Review, vol.116-4, p.890, November, 1959.

14. D。K。 Holmes. "Radiation Damage in Non-Fissionable Metals", The Interaction of Radiation with Solids, Proceedings of the International Summer School on Solid State Physics, Mol, Belgium, August $12-31,1963$, p. 147 . 


\section{DISTRIBUTION}

Number

of Copies

1

3

255

2

$$
\begin{aligned}
& \underline{\mathrm{AEC}, \mathrm{RL}} \\
& \text { C. L. Robinson } \\
& \text { AEC, RDT Site Representative }
\end{aligned}
$$$$
\text { P. G. Holstead }
$$$$
\text { J. B. Kitchen }
$$

AEC, Chicago Patent Group

G. H. Lee

R. K. Sharp (Richland)

AEC, Division of Reactor Development and Technology

J. M. Simmons

K. E. Horton

AEC, Division of Technical Information Extension

UC-40 Distribution

U.S. Naval Research Laboratory, Washington, D。C.

J. R. Hawthorne

L. E. Steele

Oak Ridge National Laboratory, Tennessee

R. W. McClung:

Argonne National Laboratory, Illinois

Harold Berger

Lukens Steel Co.2 Coatesville, Pennsylvania

R. H. Sterne 
Number

of Copies

59

\section{Battelle-Northwest}

C. A. Bennett

A. L. Bement

T. K. Bierlein

L. D. Blackburn

C. L. Boyd

S. H。 Bush

T. T. Claudson

G. J. Dau

D. R. deHalas

J. W. Helm

D。 0. Hunter

R. L. Knecht

D. C. Lehfeldt

V. I. Neeley

R。 E. Nightingale

R。N. Ord

H. N。 Pedersen

C. B. Shaw

F。 R. Shober

D. E. Simpson

J. Co Spanner

R. J. Squires

J. C. Tobin

R. G. Wheeler

D. C. Worlton

H. H. Yoshikawa

FFTF Files

Technical Information

Technical Publications 